\title{
LA ANTOLOGÍA DE LA (BUFO) COMEDIA PERUANA
}

\section{THE ANTHOLOGY OF (BUFO) PERUVIAN COMEDY}

Carlos Gamero Esparza: Universidad Inca Garcilaso de la Vega, Facultad de Ciencias de la Comunicación (Lima Perú) cgameroesparza@yahoo.com.pe

\section{CURRÍCULUM VITAE}

Periodista peruano y escritor con Licenciatura en Periodismo y Diploma de Honor al Mérito otorgados por la Universidad Inca Garcilaso de la Vega (Lima), nacido en la ciudad de Trujillo (Perú), de 56 años de edad, con casi 18 años de experiencia en el campo de la Prensa Escrita y la Creación Literaria; ha laborado como Redactor e Investigador Periodístico en los Diarios OJO y Correo de Lima (1986-2004) y ha realizado colaboraciones sobre temas de fondo y coyunturales en distintos medios impresos y digitales. Tiene amplia experiencia en redacción de contenidos periodísticos para revistas semanales o suplementos (dominicales y otros) de periódicos. Entre sus logros están sus colaboraciones en temas de investigación preparados para la revista en línea Vivat Academia, de la Universidad Alcalá de Henares (Madrid); también formó parte de un exitoso staff periodístico como Redactor e investigador de los suplementos Dominical y OJO Contigo, del diario OJO de Lima (publicaciones de Empresa Periodística Nacional SA - EPENSA, Lima), y como Redactor del Suplemento dominical Suceso, del diario Correo, también de esta ciudad.

\section{RESUMEN}


La caricatura de tinte político en el Perú tiene una larga historia y ha sido, por así decirlo, una de las "armas" editoriales más eficaces contra dictadores y gobiernos totalitarios o corruptos, amén de otras yerbas de esta viña del Señor. Gracias a la caricatura política, un género de expresión muy antiguo, los artistas gráficos del periodismo escrito pueden explayarse sin temor a la censura, salvo en algunos casos de excesiva presión extra-periodística ejercida desde afuera. La caricatura política, que es la que nos ocupa aquí, es tal vez la modalidad artística más expresiva dentro del campo periodístico, es la que a diario se mofa sutilmente de aquello que anda mal en el fuero público o de todo lo que podría estar mejor; son dibujos que muchas veces no están exentas de moraleja: la irreverencia punzo cortante forma parte de su stock humorístico. He aquí la historia del humor con carboncillo de por acá...

\section{PALABRAS CLAVE}

Historia del humor político del Perú - Caricatura - Anecdotario - Dibujo humorístico Político

\section{ABSTRACT}

The caricature of political taint in Peru has a long history and has been, so to speak, one of the "weapons" more effective editorial against dictators and totalitarian governments or corrupt, together with other herbs in this vineyard of the Lord. Thanks to the political cartoon, a very old kind of expression, graphic artists print journalism may dwell without fear of censorship, except in some cases of excessive extra-journalistic pressures exerted from outside. The political cartoon, which is what concerns us here, is perhaps the most expressive art form in the field of journalism, is the daily subtly mocks what is wrong in the public forum or anything that could be 
better; are pictures that are often not free from moral: Sharp cutting irreverence is part of their stock humorous. Here is the story of humor around here with charcoal...

\section{KEY WORDS}

History of political humor of Peru - Caricature - Anecdotes - Political humor Drawing

\section{ÍNDICE}

\section{Introducción}

1. Historia ilustrada de la risa política en el país de todas las sangres...

2. Cuadro a. ¿Qué significa caricatura?

3. El mico fiscalizador

3.1 Algunas portadas del devenir político-jocoso del Perú...

4. Sabía Ud., qué...

5. Recortes de Prensa

5.1 La Política de un Dibujo

5.1.1 El Miguel Ángel de Vladimiro

\subsubsection{Confesiones de parte}

5.1.2.1 Candidatos bajo la óptica de espinosos caricaturistas

\subsubsection{Sobre Lourdes Flores}

\subsubsection{Sobre Alán García}

6. Tres caricaturas peruanas más... del diario El Comercio

7. Un sorbo de humor político castizo...

8. Y para terminar, una "refrescante" parodia de Bush y Obama...

9. Fuentes

TEXTO 


\section{Introducción}

"La risa, remedio infalible..."

Selecciones del Reader's Digest.

"no concibo un humor político que sea laudatorio o pasado por agua tibia, no tiene sentido, sería ilustración pero no caricatura". Heduardo Rodríguez, dibujante de la revista Caretas.

La caricatura de tinte político en el Perú tiene una larga historia y ha sido, por así decirlo, una de las "armas" editoriales más eficaces contra dictadores y gobiernos totalitarios o corruptos, amén de otras yerbas de esta viña del Señor. Gracias a la caricatura política, un género de expresión muy antiguo, los artistas gráficos del periodismo escrito pueden explayarse sin temor a la censura, salvo en algunos casos de excesiva presión extra-periodística ejercida desde afuera. Cuando en 2004 se cumplieron los primeros 100 años de la primera edición de la revista cómica “Monos y Monadas", la decana en el arte de hacer crítica social con colores, lápiz y el carboncillo en el Perú, se tiró la casa por la ventana, y con mayor razón porque últimamente el género caricaturista ha cobrado un singular impulso en nuestro medio, gracias a las nuevas técnicas para plasmar sobre el papel, con trazos ágiles, el sentir y la diatriba y la burla y la protesta, que sino la crítica y la condena solapada, sobre hechos y personajes de la vida pública nacional. En este contexto, la absurdez de la política peruana, con sus hierbas y otras pajas, ha sido representada desde siempre con la punzante ironía del humor negro (y gris y de no sabemos con cual otro colorinche) de los grandes dibujantes de todas las épocas. Acá la caricatura es toda una tradición, y la "cachita" 1 viene con pluma y con ingenio, por así decirlo; y 
así se burlan de los politicastros de turno que para fortuna o infortunio de los paisanos de a pié, se suben (o los suben) al columpio del poder elegidos por voluntad o sin voluntad ciudadana. Se mofan también del pelotero figuretti, del patán hijo del presidente, del funcionario público que se vende al mejor postor, del juez o jueza coimeros, del empresario sinvergüenza o abusivo, de las "leguleyadas" 2 de los abogados y jueces corruptos, del congresista petulante, del delincuente de saco y corbata, de las instituciones estatales que sirven a intereses creados del régimen de turno o de particulares, del farandulero de moda, de la inmoralidad de alto vuelo, de los alcaldes malversadores de fondos municipales, del poderoso que viola los derechos de los demás, de la sociedad fatua, de la mala administración pública, de las malas legislaciones, de la pésima justicia -en un país donde la "ley del embudo" 3 o la "ley de la selva", es decir, donde manda el más fuerte, es algo cotidiano-; el trazo ágil del creativo se mofa también de los maltratos en la seguridad social o en cualquier otra entidad que preste servicio al ciudadano, de los sueldos de los burócratas.

La caricatura política, que es la que nos ocupa aquí, es tal vez la más expresiva en nuestro medio, es la que a diario se mofa sutilmente de aquello que anda mal en el fuero público o de todo lo que podría estar mejor; son dibujos que muchas veces no están exentas de moraleja: la irreverencia punzo cortante forma parte de su stock humorístico. El caricaturista hace reír poniendo en ridículo las malas artes políticas y públicas de personajes que, supuestamente, están donde están para servir a la sociedad y no para servirse de ella, y lo hace con la corrosiva acidez y los recursos que le proporcionan su impresionante creatividad, dando vida a su mundo de colores encendidos -que sino en $\mathrm{b} / \mathrm{n}-$, exagerando rasgos, personalidades, atributos, comportamientos y cualidades de prójimos y prójimas de postín, tratando de resaltar lo malo y lo bueno, lo verdadero y lo falso, venteando los siete pecados capitales de esta sociedad en la que se revuelve la absurda contradicción humana. 
Para los estudiosos, una caricatura representa muchas cosas, es a la vez "caricaturizar" lo que no se nota a simple vista como también aquello que se nota, simbólicamente, a una realidad; es, en todo caso, una forma de llamar la atención, humorísticamente, sobre actitudes, comportamientos, circunstancias, hechos o acciones de personas o colectividades. De allí que se puede decir que el "modo" en que se muestra la actuación de un personaje, grupos de individuos o situaciones circunstanciales puede resultar "caricaturesco, a", es decir, la exageración de ciertos rasgos de las peculiaridades humanas y sus acciones plasmada en el papel o en "vivo" -acto teatral o televisivo-. Pero la caricatura en el Perú ha seguido una trayectoria muy particular, a diferencia de otras manifestaciones artísticas similares; lo político, como ninguna otra forma de expresar el humor gráfico, manifiesta con agudeza la idiosincrasia perulera, que, como verá el amable lector, poco ha variado a lo largo del tiempo... las ideas, la actitud, el comportamiento, las formas de asumir los hechos, las motivaciones, los estilos y hasta los dobles discursos son gotas del mismo charco... y de la (bufo) comedia peruana...

1- Cachita. En el Perú esta voz es sinónimo de ironía (burla, mofa, desdén). Por eso se dice: "no me hagan cachita porque me amargo fuerte y nadie va a responder los golpes..." Diccionario de Argot Limeño o Jerga Criolla del Perú, de Guiullermo E. Bendezu Neyra, Editorial Universo, La Victoria, Lima, 1970

2- Leguleyada. Dícese de las argucias jurídicas ejecutadas por uno de esos representantes que tanto mal le hacen a la honra y buen nombre de los abogados. Blog de Carlos Caicedo. http:/ / carloscaicedo.wordpress.com/page/3/ (30/2/2010)

3- Este término es una expresión acuñada popularmente para denunciar una injusticia surgida en alguna confrontación o disputa. El mandato único de esta ley 
puede resumirse en: "La ley del embudo/lo ancho para otros/lo estrecho para uno" (refrán), en referencia a la forma del embudo.

Es una locución muy común en los países de habla castellana. Es una "ley" contraria a los principios de igualdad ante la ley y de equidad; el uso de esta locución, en algunos casos, puede llevar implícita una crítica contra los poderes fácticos y, entonces, formaría parte del ideoléxico.

http://es.wikipedia.org/wiki/Ley_del_embudo (1/3/2010)

\section{Historia ilustrada de la risa política en el país de todas las sangres...}

(Nota: algunas de las ilustraciones a continuación no han sido colocadas cronológicamente, adrede, para que el lector pueda apreciar el contraste de épocas y pensares en el devenir de la cotidianeidad política y social)

Lo que sigue es un resumen de la incalculable creatividad del caricaturista peruano a través de los años, desde la época de la llamada "Prosperidad falaz" de la segunda mitad de los años 1800s.

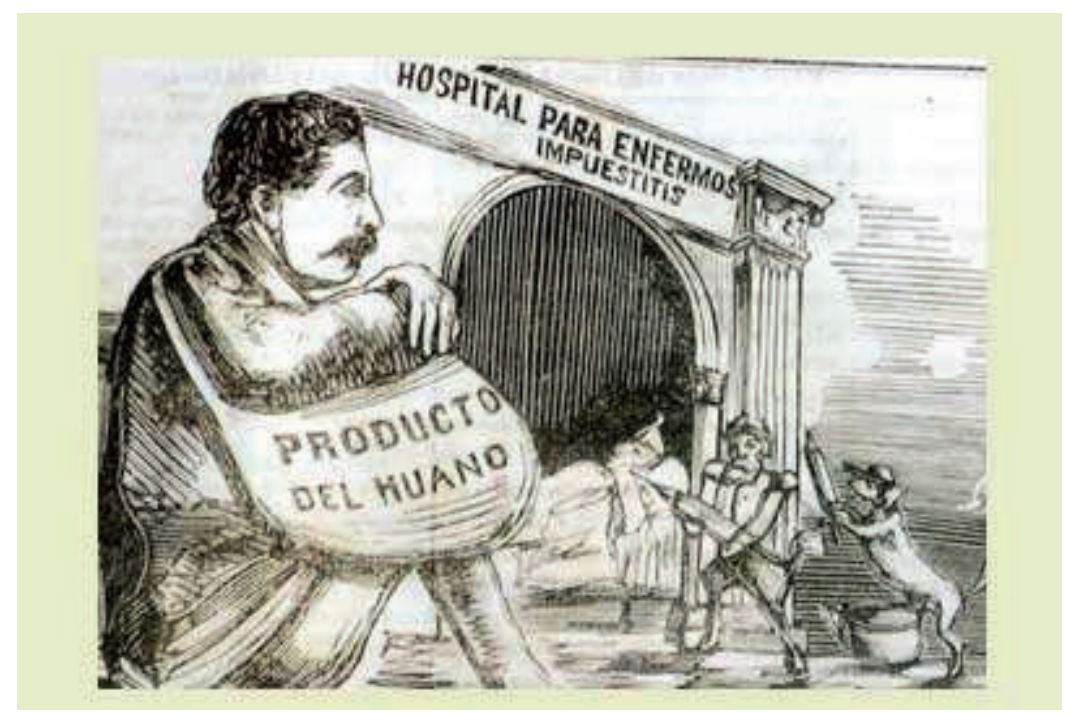


Los políticos del S. XIX la vieron negra, como refleja esta caricatura publicada en el diario El Cascabel en 1872, justo en plena época de la crisis provocada por el mal manejo de nuestra economía, previa a la Guerra con Chile; aquí se observa al presidente José Pardo como causante de una enfermedad llamada impuestitis. 4

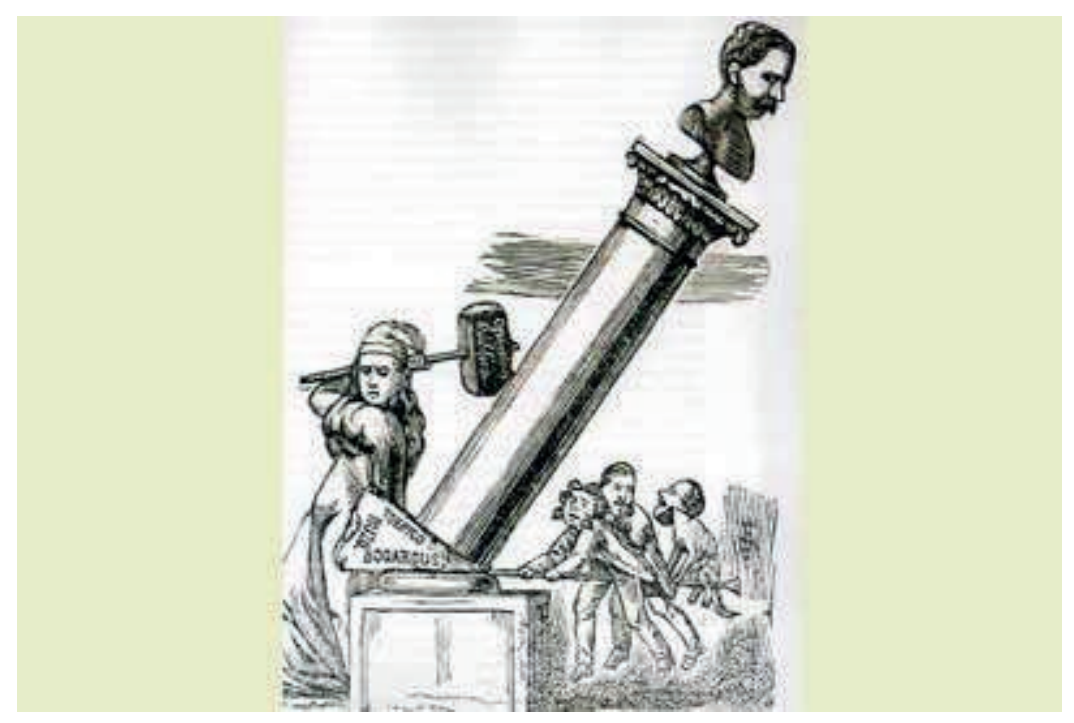

La Patria... contra Pardo. En el Perú nadie estuvo a favor de las consignaciones del guano que firmó el gobierno de ese entonces (1872). Así lo podemos apreciar en esta caricatura, donde la Patria, en representación de la opinión pública, y con el sustento de los enemigos de Pardo, derriba el monumento que representa al gobierno. 5 


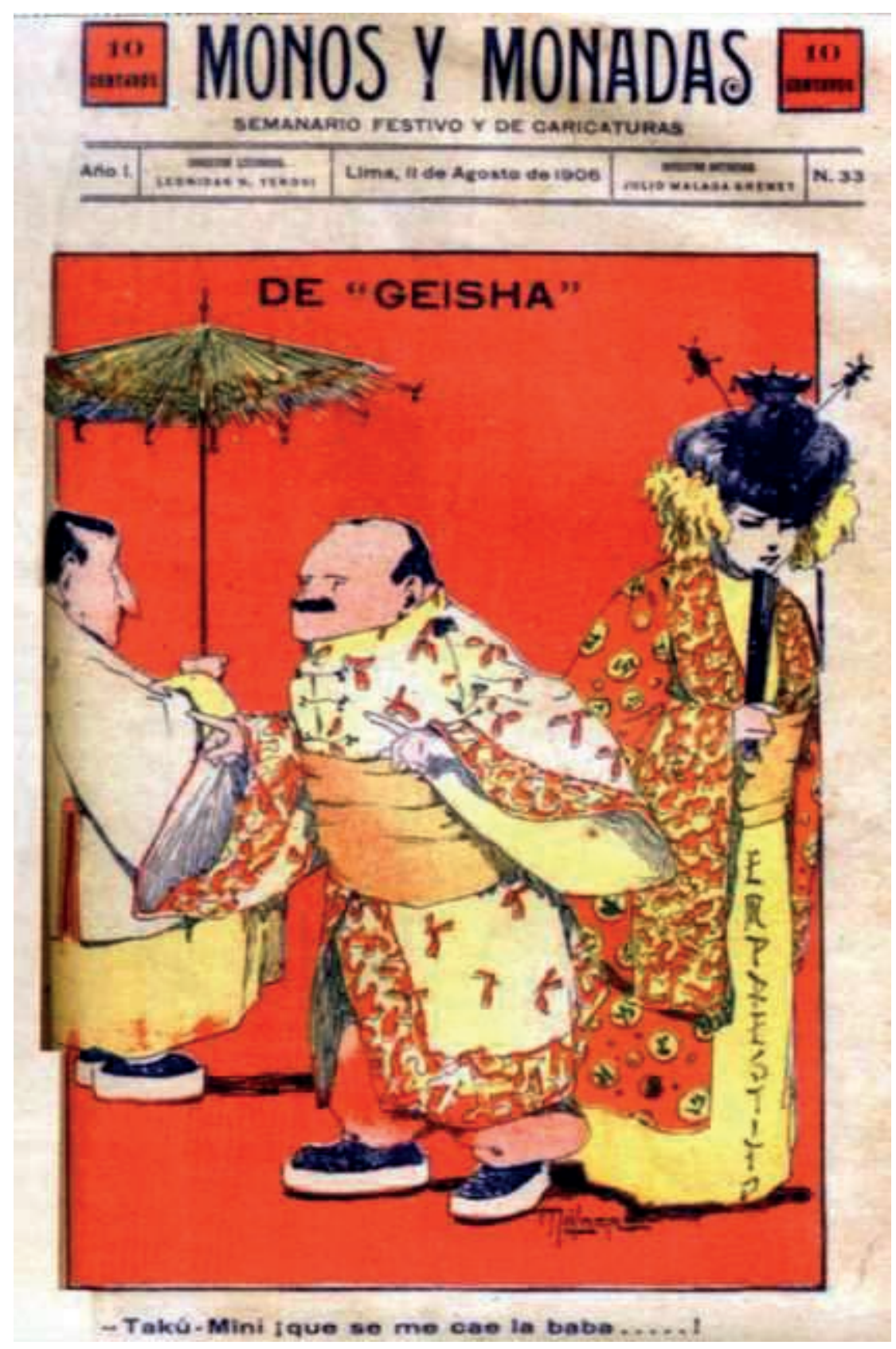

Hizo historia. Monos y Monadas 033 del 11 de Agosto de 1906 (hace casi 104 años atrás!). La ilustración de la portada es de Julio Málaga Grenet, un reconocido caricaturista que retrató al presidente civilista José Pardo dando órdenes al entonces ministro de hacienda, Don Augusto B. Leguía, para que acepte las condiciones de un préstamo otorgado por el Japón. Pensar que, casi un siglo después, siendo presidente, en el año 2000, Alberto Fujimori cargaría con todo y se lo llevaría a Tokio 
en no sabemos cuántas maletas (dicen que fueron 48, pero hasta ahora nadie las ha visto, pero hubo testigos de este hecho). 6

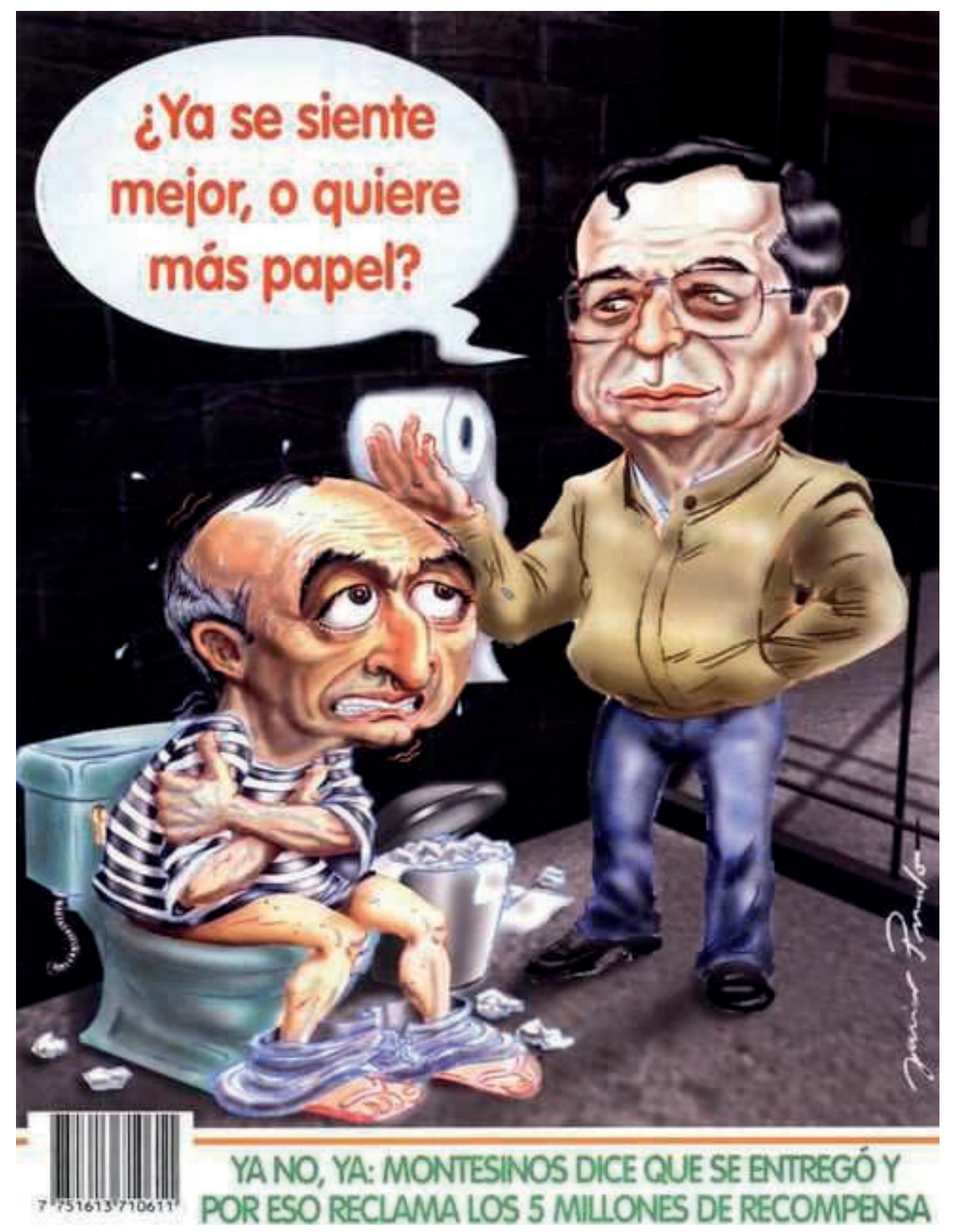

Fuji y el Doc. Monos y Monadas 532 del 30 de Junio del 2001, carátula dibujada por Javier Prado. Como es evidente se trata de de la revista que muestra la captura del socio de Fujimori su gemelo Montesinos, buen momento para recordar que los delincuentes no pueden tener los mismos derechos que el ciudadano común. Como 
la revista y sobre todo la portada se realizaba días antes del cierre por su complejidad a veces el tema de la portada podía quedar desfasado, para esta caratula esperábamos la confirmación de la noticia que al inicio solo era un rumor así que con más prisa que de costumbre se hizo el mismo día antes de llevar los artes a la imprenta. Texto de Nicolás Yerovi. 8
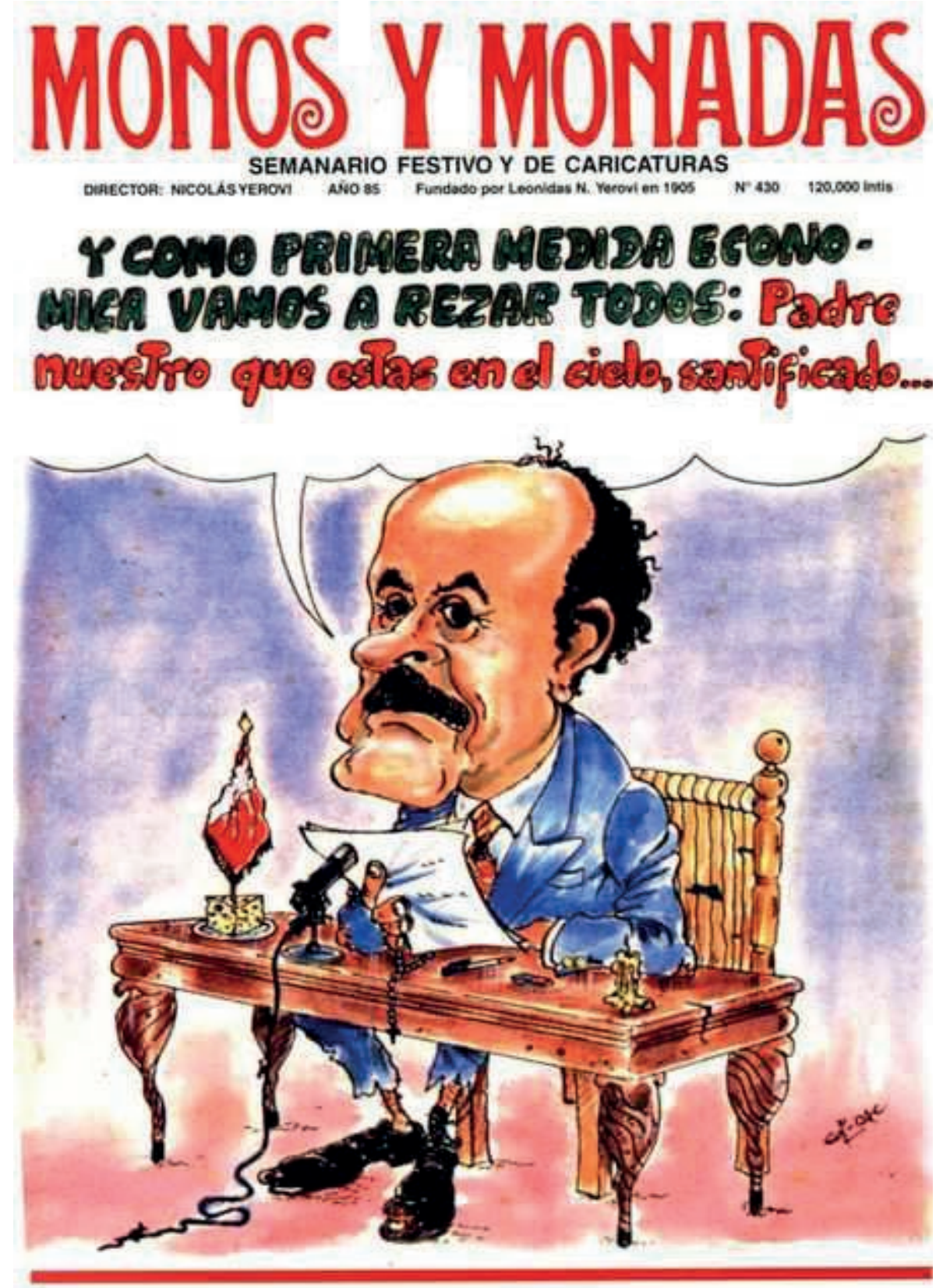
Haciendo cada vez más una involuntaria demostración de poderes adivinatorios, en la mañana del 8/08/90 MONOS y MONADAS publicó esta carátula donde aparecía el entonces ministro de economía, vestido astrosamente (sic. $\mathrm{N}$ de VA) para conmover al país, rezando en público. Horas después, Hurtado Miller se dirigiría a la nación anunciando el tantas veces negado FUJISHOCK . Los bien pensados creyeron que por vergüenza, ya que se había asumido la Presidencia de la Republica esgrimiendo la frase "No Shock" seria el mismo chino quien daría el mensaje disculpándose acaso por esta su primera mentira de las muchas que se dieron en su gobierno. Ahora sabemos que lo que le sobro fue cobardía a falta de vergüenza. Y el ministro que dio la cara para anunciar el Shock económico termino precisamente como lo había predicho esta humilde publicación: invocando un "que Dios nos ayude!! (sic).Texto de Nicolás Yerovi. 9 


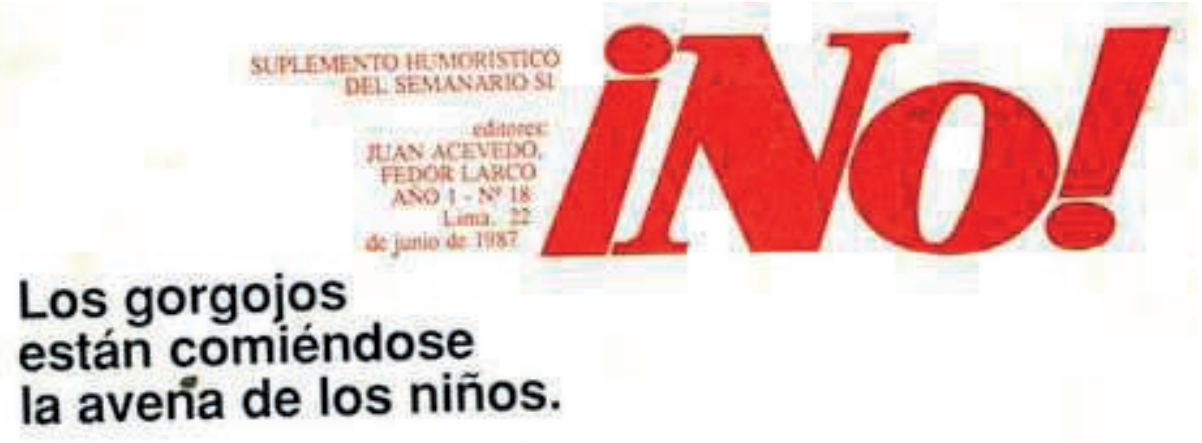

\section{La leche se pudre en la galería de arte "Pancho Fierro".}

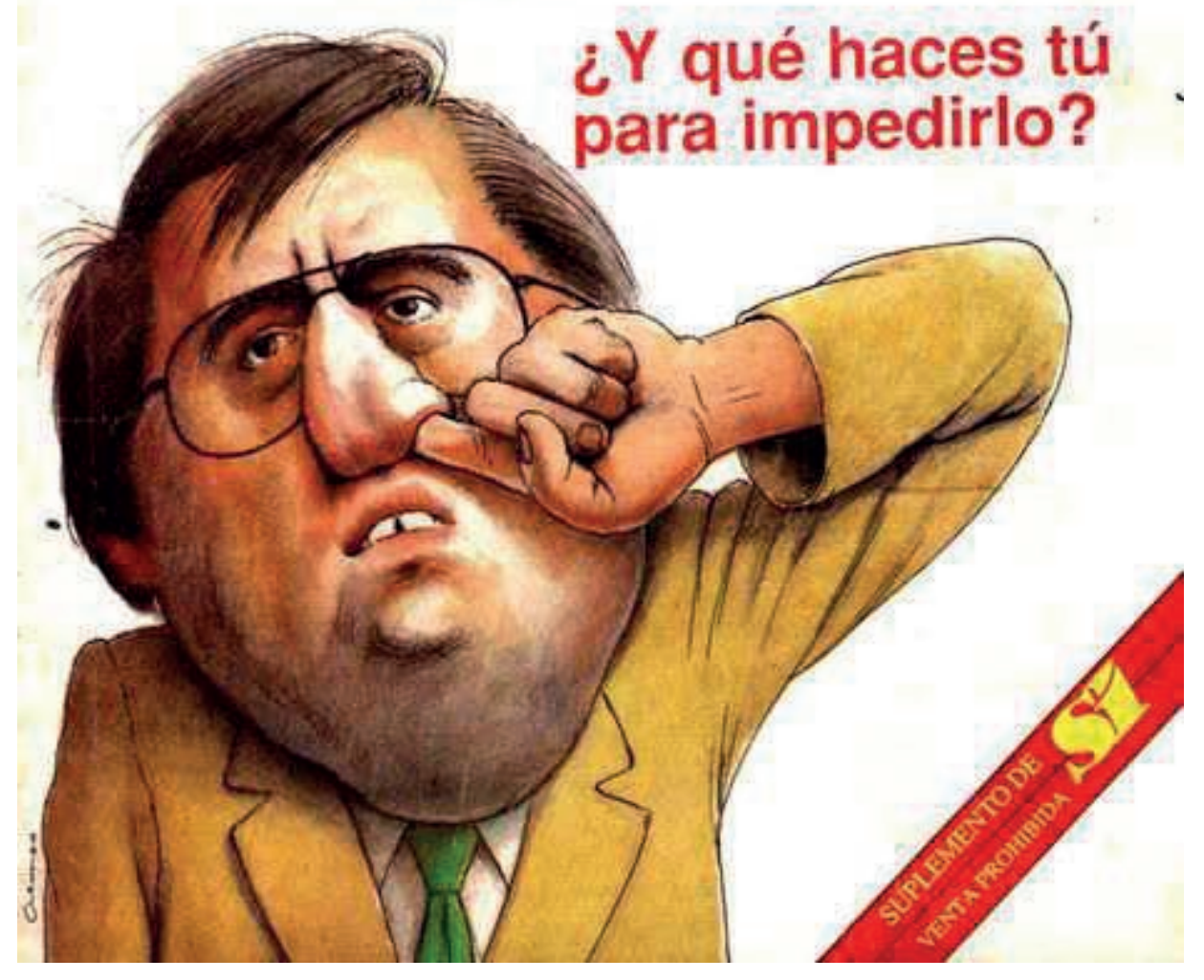

La revista ¡No! El grupo editorial de la familia Marsano, que también manejaba el semanario de corte político Sí y el recordado diario El Sol, quiso hacerle la sombra a Monos y Monadas y sacó la revista ¡No!, un encantador magazín de corte humorístico que por algún tiempo llenó los quioscos con el sano y punzante humor político de sus caricaturistas. Aquí vemos retratado a quien fuera primer ministro de la actual gestión de Alan García, Jorge del Castillo, cuando este era alcalde de 
Lima, en la que muestra su preocupación por el llamado "Vaso de Leche", un programa social de lucha contra la desnutrición infantil que él ideó, el mismo que fue su caballito de batalla política en aquel entonces. Hoy, 23 años después, este ha sido el programa de asistencia alimentaria más exitoso de nuestra historia. Portada de la edición del 22 de junio de 1987. 10

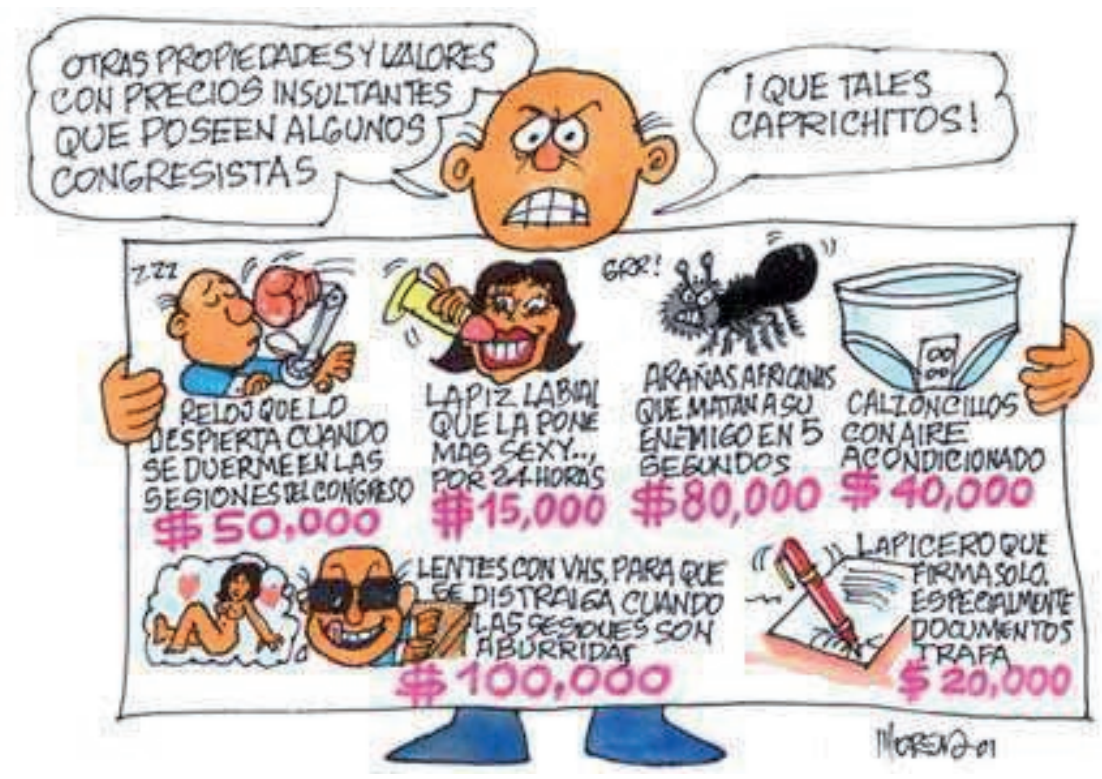

Para hacer escarnio de la indignidad humana, en el 2001 el dibujante Mario Moreno publicó este dibujo en su blog (actualmente desactivado), donde las cifras que se muestran no tienen nada que ver con la ficción... hasta hace pocos años, cuando la economía peruana anduvo de ca-be-za..., mientras ciertos vivazos enquistados en las esferas del poder hacían de las suyas, cuando el resto del llano vivía una y mil carencias. Por cierto, este dibujo es, en el fondo, una velada crítica contra la corrupción imperante durante la dictadura fujimorista. 11 


\section{TNo pregunte, que pienso de el." 18 Diciembre 1997.}

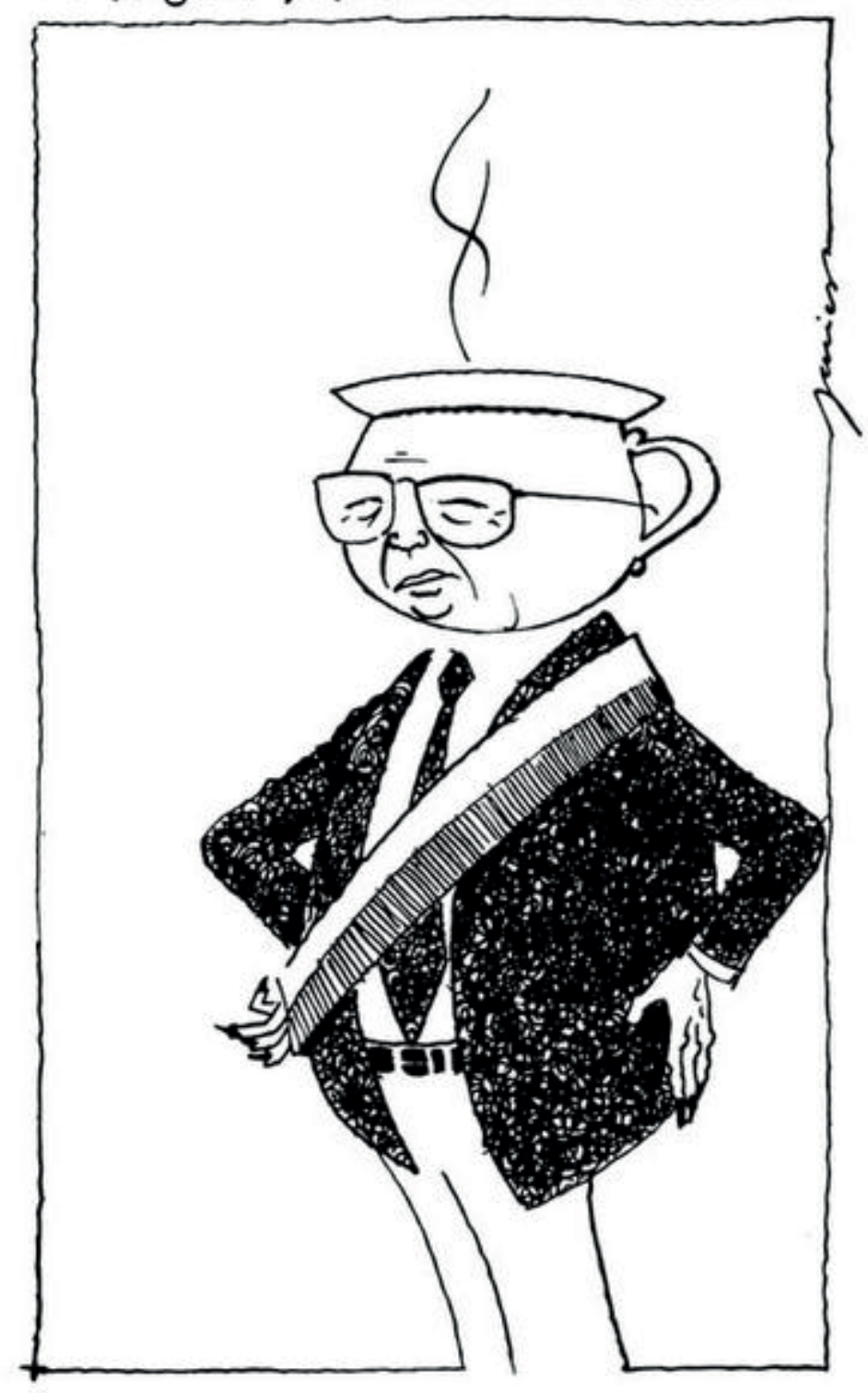

Bacimori. Cuando en los 90s le preguntaban a Javier Prado, dibujante del diario El Comercio, qué era lo que se sentía respecto a Alberto Fujimori, no está demás decir, a su gesto de asco se añade este dibujo que hizo en 1997, donde retrató al dictador tal como era (y todavía es percibido) por muchos peruanos, ahora con el ex mandatario en prisión, purgando por sus crímenes de lesa humanidad. 12 


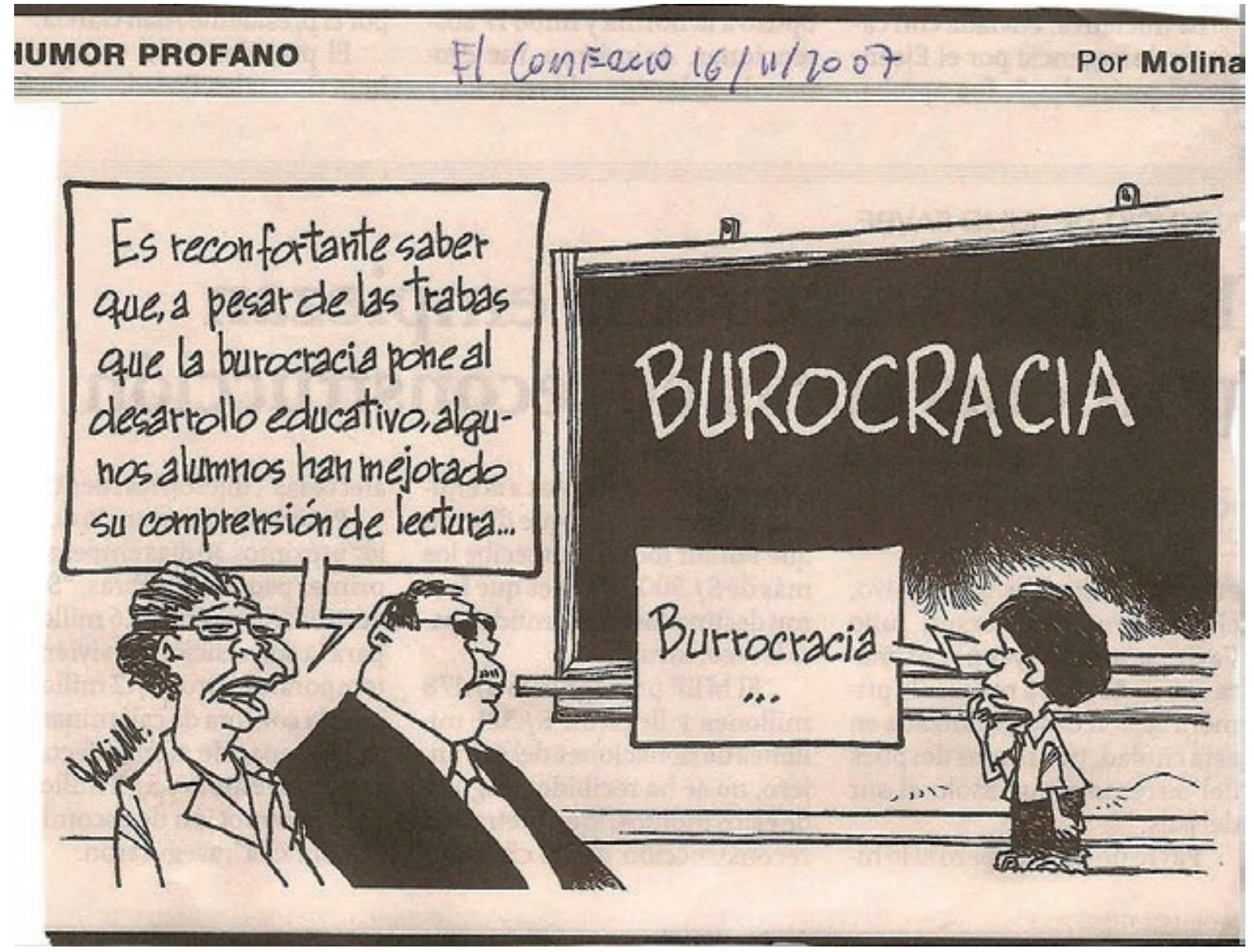

Burrocracia. En 2007, el Ministerio de Educación del Perú dio inicio a una supuesta "reforma educativa" en los colegios públicos, pero lo hizo de una forma tan desatinada, que los resultados no se hicieron esperar. Aquí, Molina, dibujante del diario El Comercio, en su sección "Humor Profano", hace mofa de "las mejoras" de las que tanto se jactó en ese entonces José Chang, el entonces ministro del sector; empero, lo que los funcionarios gubernamentales no tomaron en cuenta, en esta supuesta "mejoría" de la calidad educativa en la población escolar, fue que no habían hecho nada para dar facilidades e incentivos a los maestros para que estos puedan realizar su labor con mejores resultados... lo que hicieron en realidad fue mandarles un cargamontón de exigencias burocráticas que dificultaron en mucho la labor pedagógica. Y encima les achacaron a ellos -los maestros - el mal aprendizaje de muchos escolares, cuando en realidad era el propio sistema “burrocrático" el que 
había hecho todo lo posible para hacer difícil lo fácil, y las autoridades educativas, en un alarde de soberbia, no quisieron reconocer su error. Cierto o no, para nadie fue un secreto, entonces, que la "reforma educativa" de marras fue un fracaso más (hasta ahora), y todo porque esta parecía haber sido diseñada para hacerles la vida imposible a los docentes en el cumplimiento de su loable labor. Esta caricatura, como habrá visto el amable lector, vale por mil palabras. 13

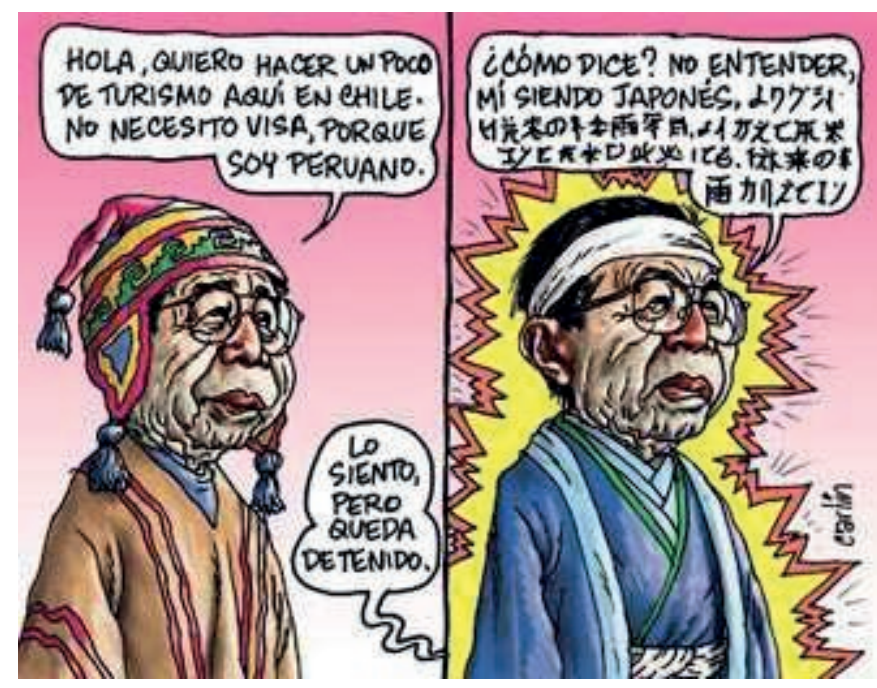

El 7 de noviembre del 2005, el prófugo Alberto Fujimori Fujimori, acusado por la justicia peruana por sus crímenes de lesa humanidad y otras perlas, sorprendió al mundo apareciéndose por el Aeropuerto Internacional de Santiago, procedente de Tokio, donde estaba refugiado desde su vergonzosa huida del Perú tras la caída de su corrupto régimen (fines del 2000); al verse literalmente acorralado por los carabineros chilenos y la Interpol, Fujimori se identificó primero como ciudadano peruano para confundir a las autoridades de este país. Esta caricatura de Carlín, dibujante de La República, retrata, pues, la contrariedad del ex mandatario... al contradecirse diciendo que era japonés cuando se le comunicó que iba preso. El "chino", como le dicen sus seguidores, qué duda cabe, había metido las cuatro. Ilustración publicada en El Blog de Aronyaqp 14 


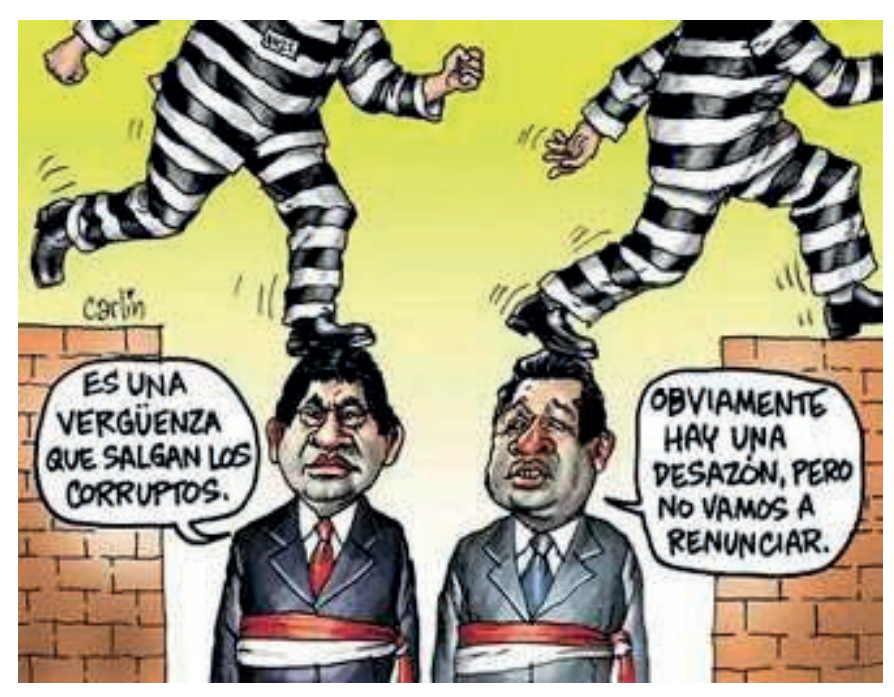

En sus narices. Aquí Carlín, en el diario La República, retrató la impotencia y la indignación ciudadana al constatar la forma escandalosa cómo malos jueces liberan tanto a corruptos como a delincuentes de postín bajo las más increíbles excusas legales, dignas de ripley, que hoy todavía se ven, con la liberación de oscuros personajes que cuando estaban en el poder hicieron y deshicieron cuanto quisieron, robaron y violaron derechos ciudadanos sin asco, y que hoy están libres de polvo y paja por ese arte de birlibirloque que solo se ve en el Perú. 15 


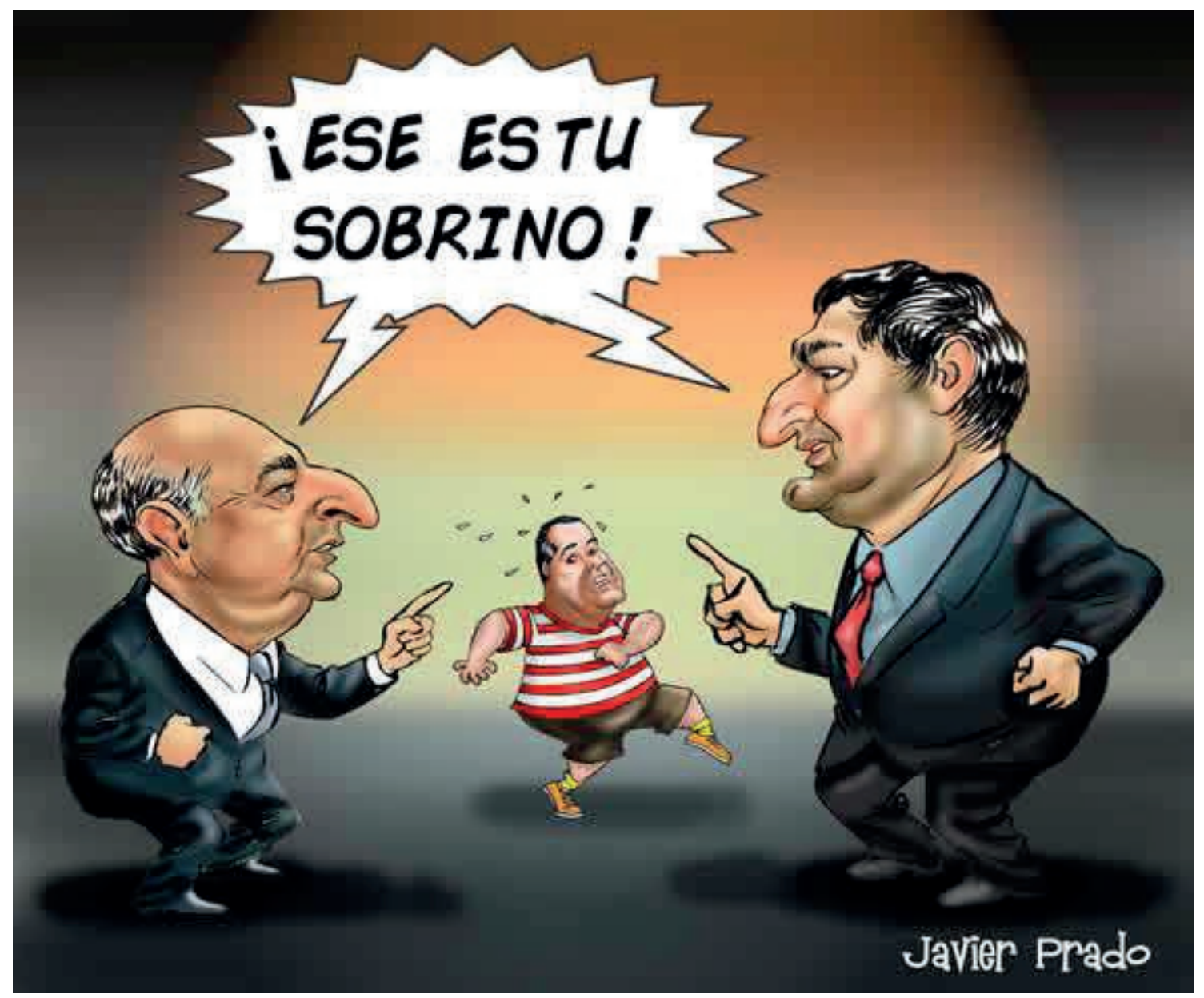

"Sobrinitis" (además de hermanitis, tiítis, ahijaditis, hijitis, cuñaditis, yernitis, nueritis, compadritis, espositis, primitis, abuelitis, nietitis...), fue la marea que inundó la gestión Toledo de parentelas de todos los colorinches durante los cinco años de la Chacana 16. Como nunca antes se había visto, los sobrinos y demás hicieron de las suyas aprovechándose del puesto del hermano o del tío, y, como ya es usual en el país de las maravillas, la ley anti-nepotismo fue letra muerta, como podemos apreciar en esta caricatura de Javier Prado, dibujante de El Comercio. 17 


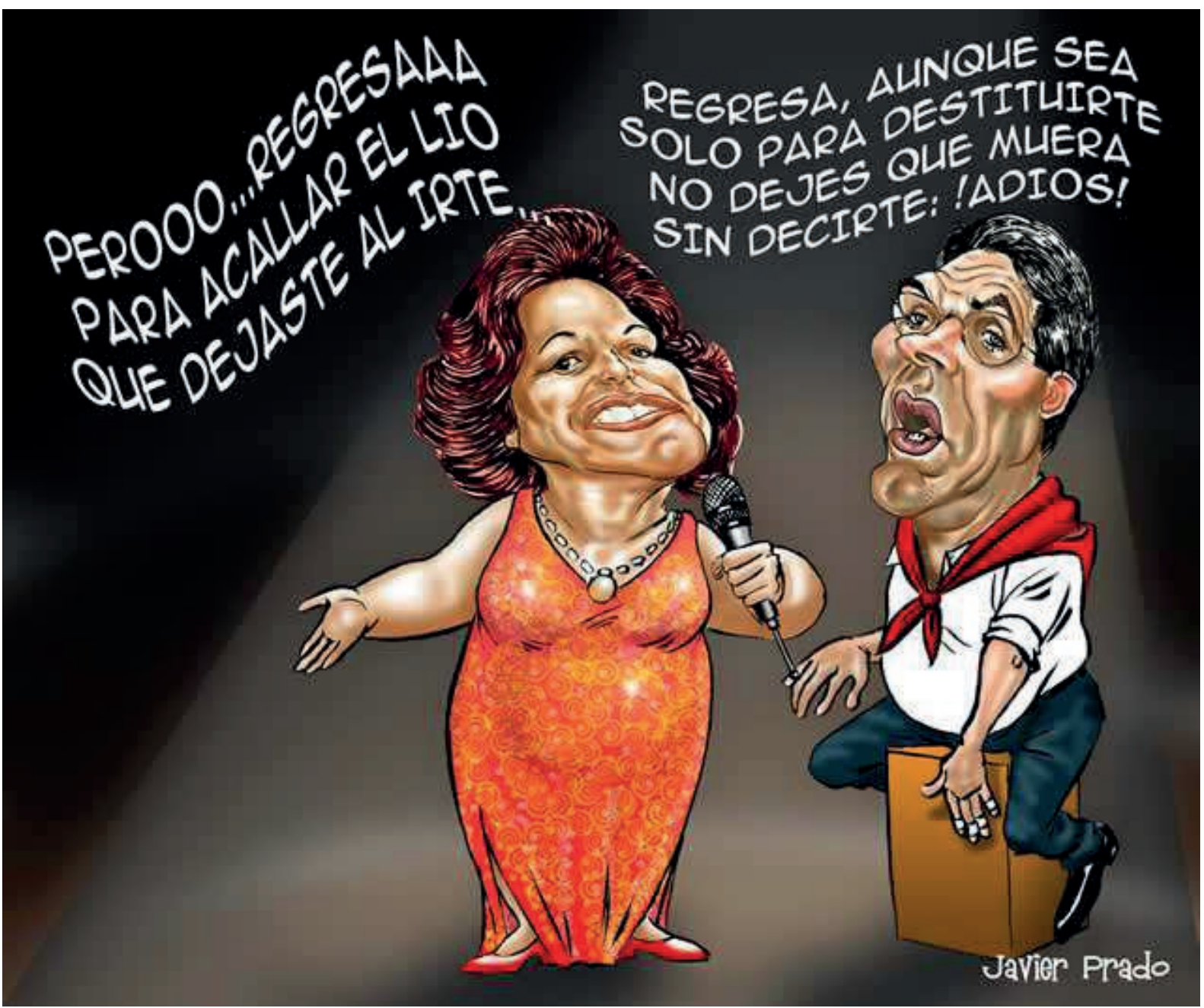

No perdieron el tiempo. Esta caricatura es de la época (en pleno 2005) cuando ciertas voces comenzaron a hablar de vacancia presidencial, rumor que atizó expectativas, incluso de personajes que en ese entonces aspiraban a la presidencia, como vemos en este gracioso dibujo de Javier Prado, de El Comercio, donde Lourdes Flores y Ollanta Humala (quiénes son sus rivales políticos) le cantan el vals "Regresa" a Alejandro Toledo -emulando a Lucha Reyes, una recordada cantante criolla, ya desaparecida - , aunque esperamos que eso no se dé nunca... ahora que pretende, otra vez, lanzarse como candidato para el 2011. 18 

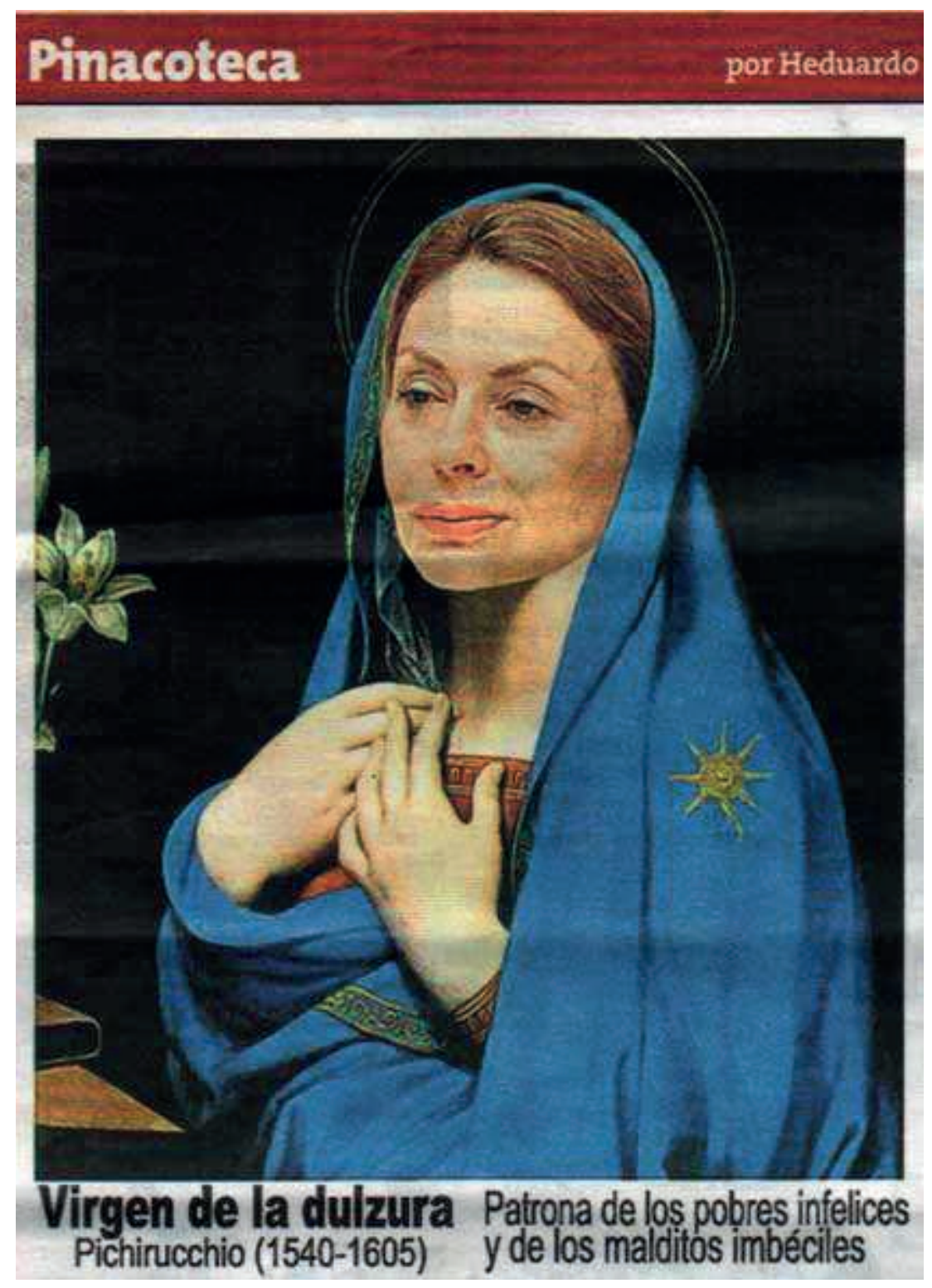

Si hubo una inquilina de turno en la política peruana que se ganó con todo merecimiento el premio limón de la antipatía pública, esta fue, seguro, la esposa del ex presidente Alejandro Toledo, la antropóloga belga Eliane Karp. Este personaje, polémica por sus oscuros manejos en los programas sociales que ella administraba, se volvió célebre por sus intolerables "impromptus" mediáticos plagados de insultos y términos xenofóbicos; por este motivo, la ahora (igracias a Dios!) ex primera dama ha sido ácidamente retratada como una mujer pelirroja de tez agringada, de mirada agria y postura adusta, que parece escupir su odio sobre quién se atreva a no estar de 
acuerdo con sus peculiares e inaceptables puntos de vista. El caricaturista de La República, Heduardo, se inspiró en esta renacentista "virgen de la dulzura" para lograr tales rasgos (a ver si la Madre de Dios la ilumina... para bien de su salud moral y mental... y también la tranquilidad nuestra, pobres plebeyos, que tuvimos que soportar impertérritos sus mordaces desatinos) Ilustración publicada en el blog El Foro de Kaliman.19

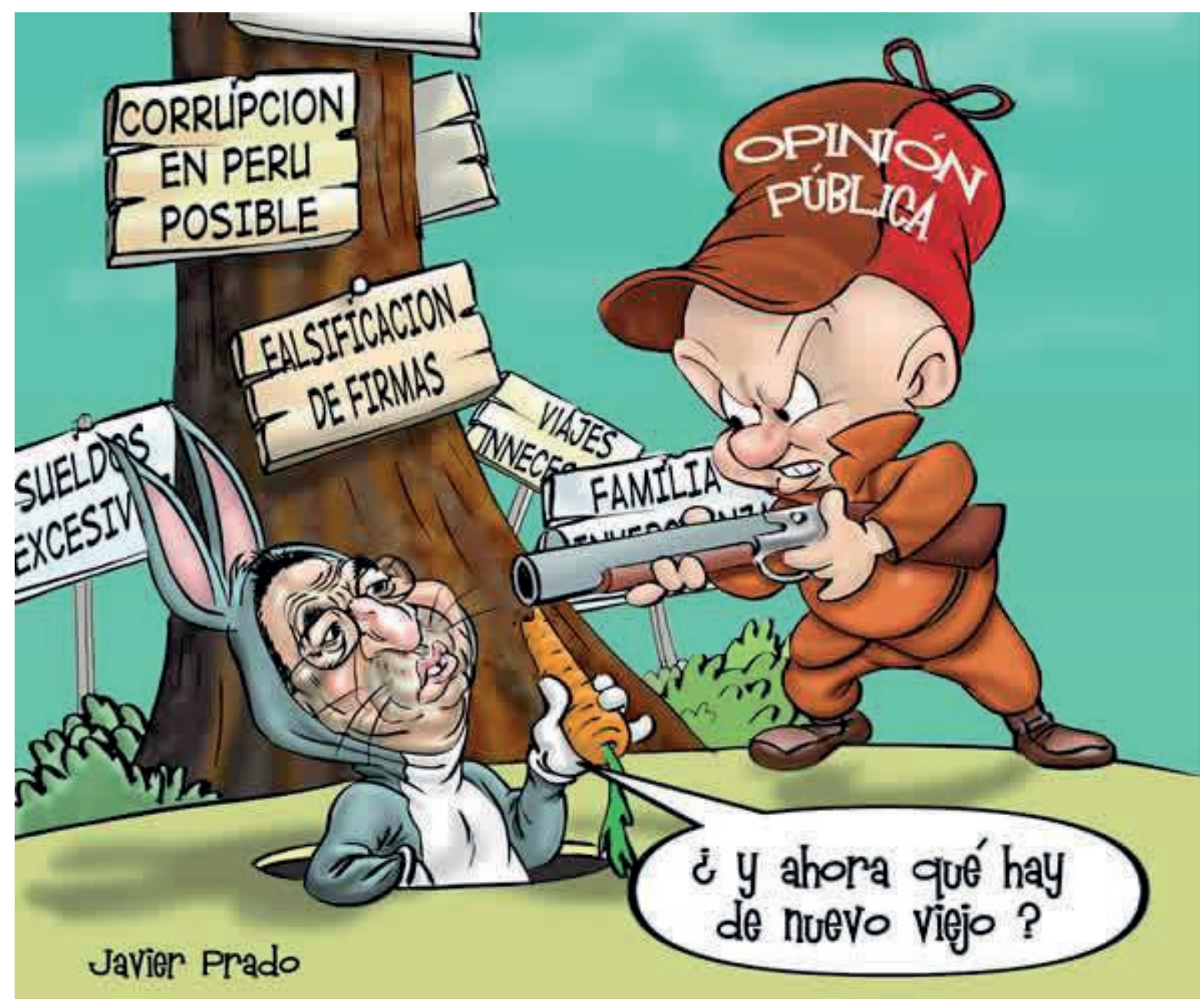

¿Qué hay de nuevo Viejo?, pues parece que lo mismo de todos los días, el gobierno insiste oligofrénicamente en darse golpes solos y acusar a otros de ser los causantes. Texto e ilustración de Javier Prado. 20 


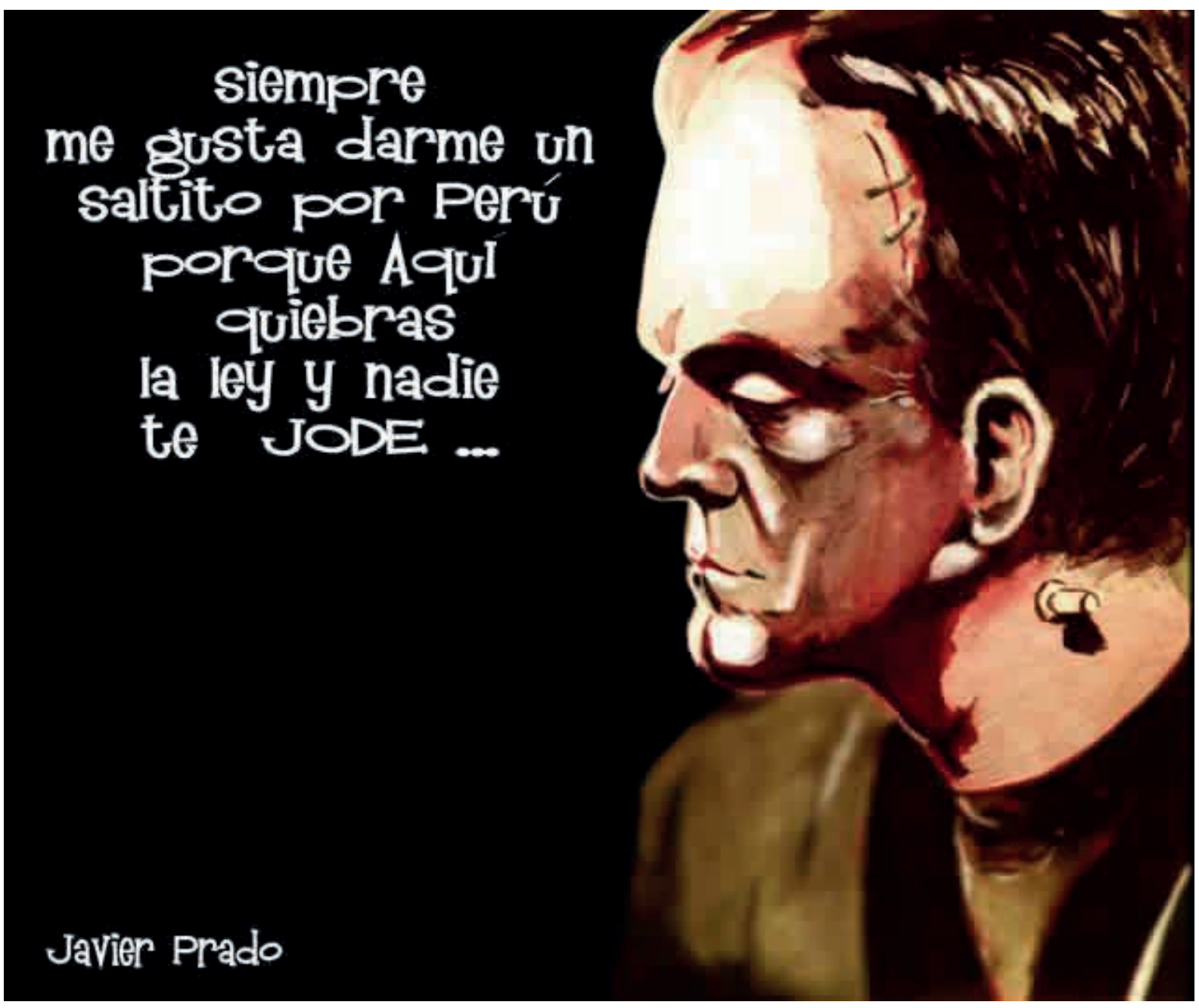

"Colinas" sueltos por las calles. Varios de los integrantes de aquel sanguinario "Grupo Colina”, causantes de las masacres de La Cantuta y Barrios Altos (Lima), acaecidas en 1992 --en plena dictadura fujimorista - , hasta la fecha siguen cantando "libertad, libertad", sin que nadie les ponga la mano encima, aunque afortunadamente algunos de estos esbirros, entre ellos su líder, el oficial Santiago Martín Rivas, ya están contando calendarios tras las rejas. Pero de los que todavía andan sueltos en plaza, ni la tos. Así los retrata Javier Prado, viviendo en el país de las maravillas, donde ni siquiera Frankestein está seguro de no sufrir una crisis de espanto por tanta impunidad e injusticia. 


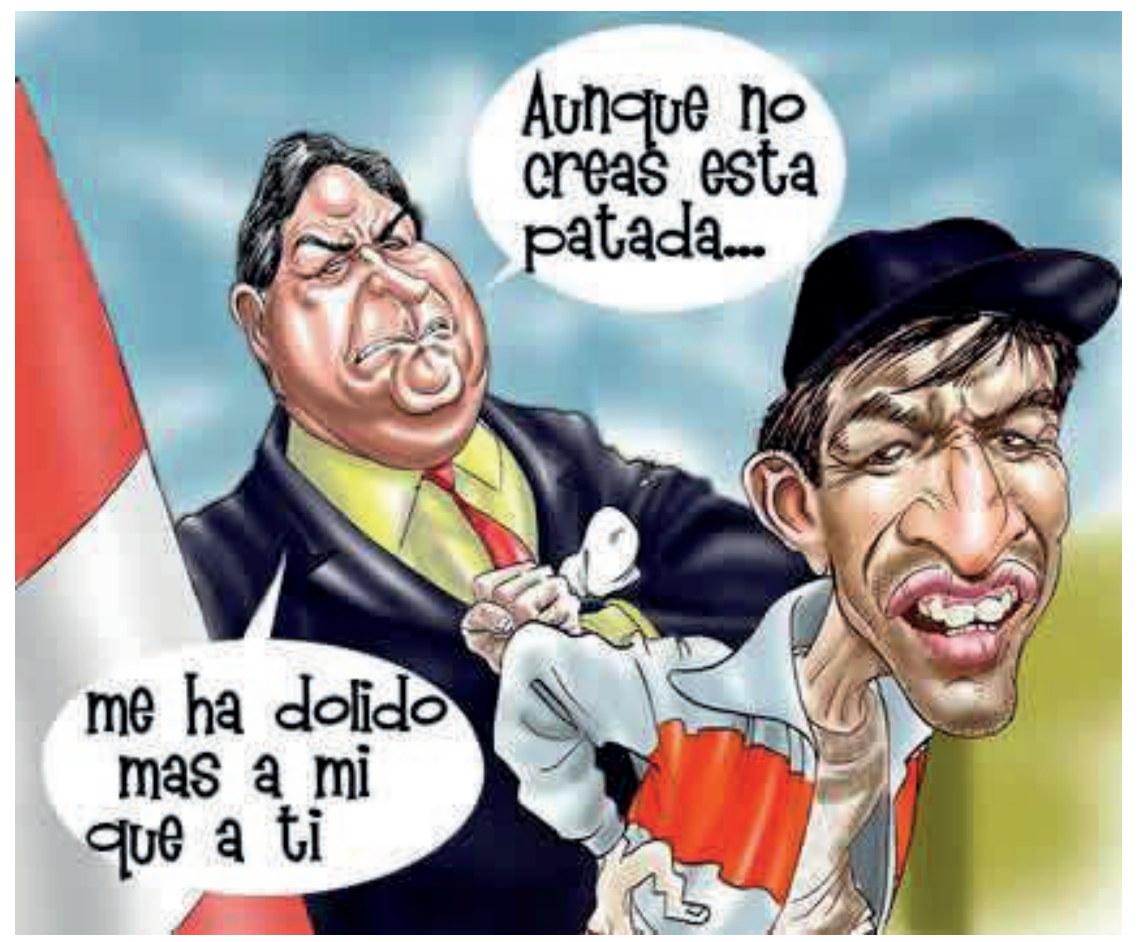

El 5 de enero 2005 pudo ser una fecha aciaga para las aspiraciones presidenciales del entonces futuro candidato aprista Alan García. La "patada" que le propinó a Jesús Lora, un humilde trabajador discapacitado, durante una marcha sindical de la CGTP * por el centro de Lima casi hundió su fulgurante carrera política. Se salvó de milagro... por esas cosas que solo pasan en el Perú. Caricatura de Javier Prado, diario El Comercio.

*Confederación General de Trabajadores del Perú (qué más está decirlo...) 


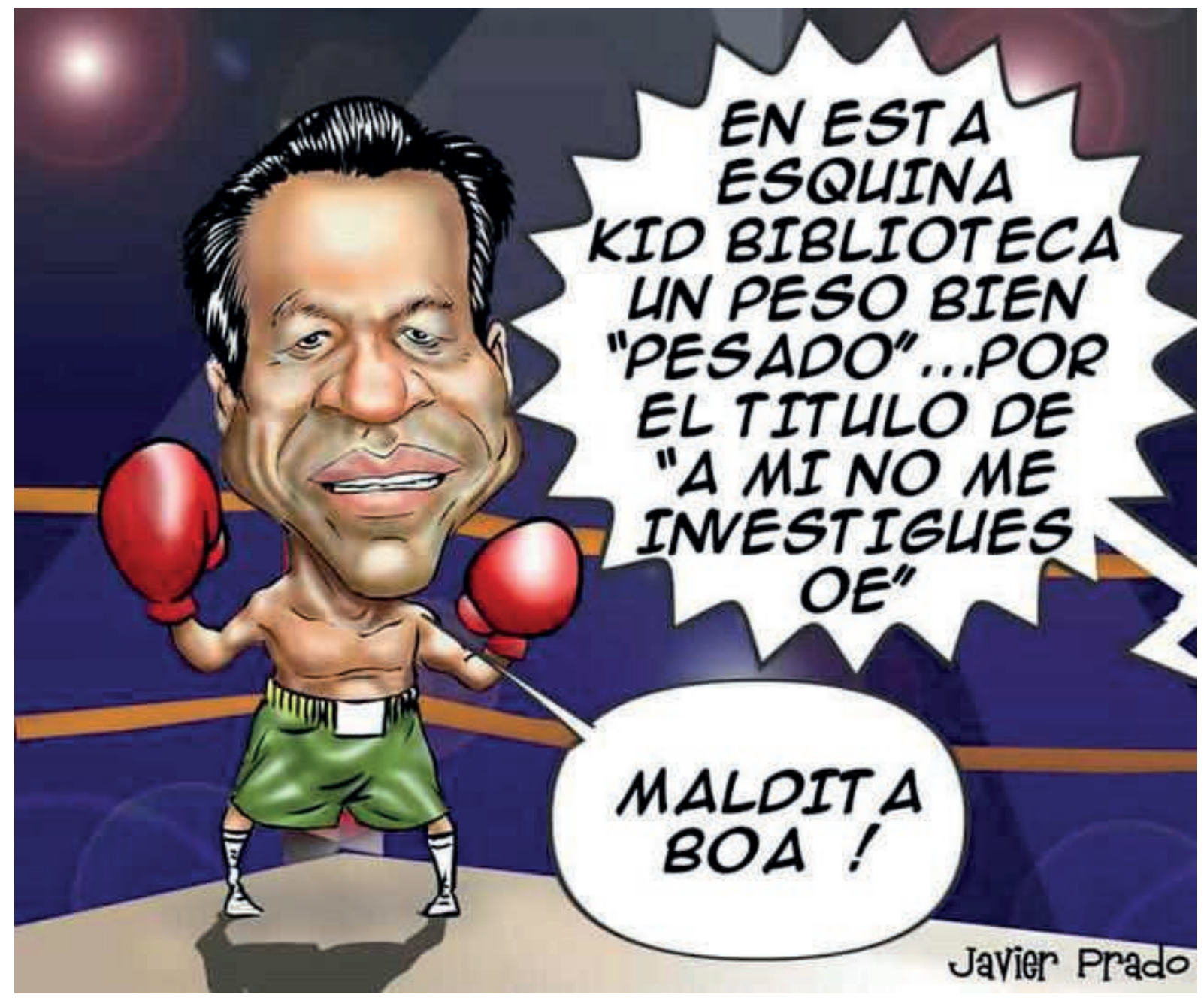

Víctor Valdez era un congresista de la época de la ilustre Chacana (durante el gobierno de Alejandro Toledo 2001 - 2006) que cobró notoriedad no precisamente por sus cualidades de legislador sino por bocón. Decir que su biblioteca costaba tantos millones de dólares le mereció una investigación parlamentaria y una suspensión de su fuero legislativo. Como vemos en esta graciosa caricatura de Javier Prado, de El Comercio, sus poses de "figuretti" le costaron muy caro al señor Valdez, por eso se hizo merecedor del descrédito nacional, y con mayor razón, si es que pretende volver al Parlamento... mejor que ni se le ocurra. 


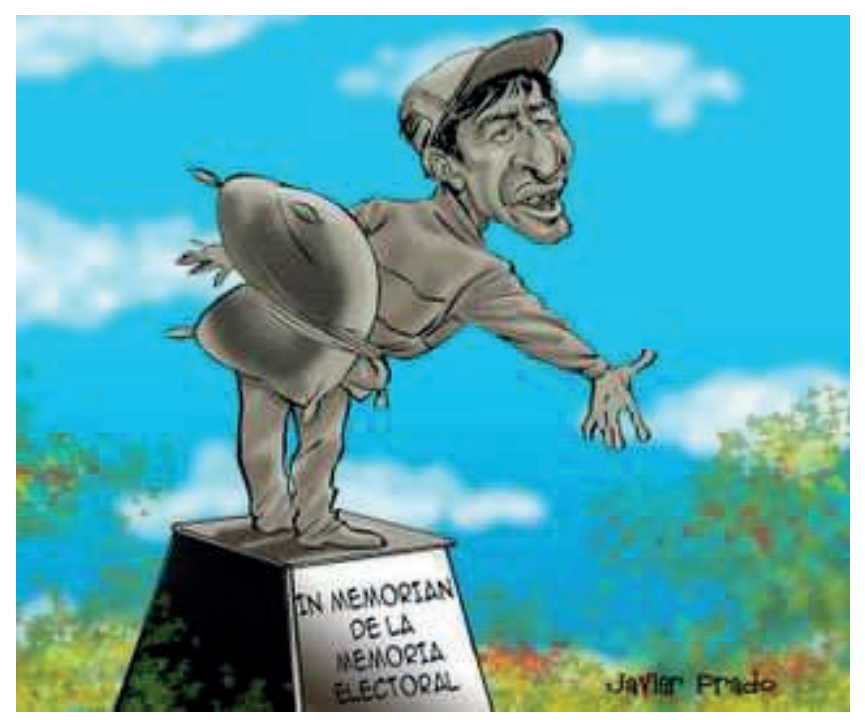

Ahora que se acercan los comicios electorales para elegir a alcaldes y regidores en todo el Perú, para noviembre del presente año, paso previo para las presidenciales del 2011, qué mejor advertencia a los electores, para que tengan memoria electoral y aprendan a elegir a los mejores candidatos y no a cualquier sinvergüenza que se quiere aprovechar de la credulidad del vulgo para llegar al poder de turno; sí, qué mejor forma de "recordarlo" que este singular "monumento" donde se ve a un adolorido ciudadano con cara de piedra y los rasgos de un pintoresco personaje que hace un tiempo protagonizó uno de los hechos más curiosos de nuestra desconcertante historia reciente: Jesús Lora, aquel humilde trabajador que, sin quererlo, se puso en el camino del hoy presidente Alan García durante una marcha sindical en el año 2005. Fue en aquella ocasión cuando el buen Lora recibiera el memorable "puntapié" en ya saben dónde, que lo llevaría, sin embargo, a un fugaz estrellato. Con el caso de este paisano se resume una realidad patética en la vida política peruana: la desmemoria del hombre de a pié acerca de las consecuencias de elegir siempre al peor gobernante. Y lo paradójico del asunto es que, en este momento, ya nadie se acuerda del incidente de "la patadita”. ¡Con cuánta razón el genial dibujante peruano Javier Prado hizo esta, tal vez premonitoria, caricatura, casualmente publicada en julio del 2005 en el diario El Comercio y también en La Nuez. 21 


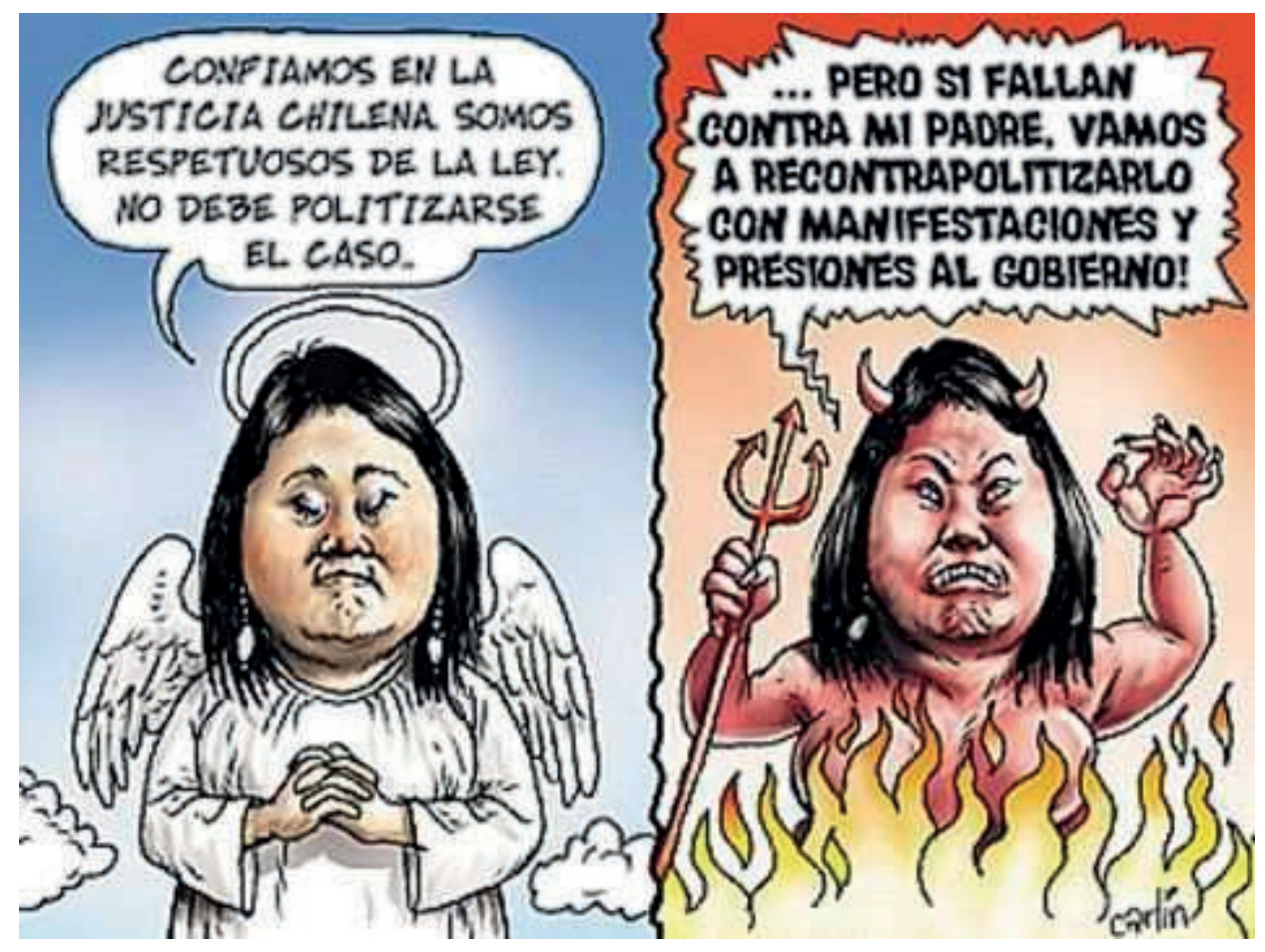

Para cerrar este dossier, nada mejor que insertar esta caricatura del genial dibujante del diario La República, Carlos Tovar (Carlín), quien, durante los días previos al fallo de la justicia chilena, que finalmente decidió extraditar al ex mandatario Alberto Fujimori al Perú para que sea juzgado por sus crímenes, trazó este dibujo en el que podemos apreciar la doble moral de su hija, la congresista Keiko Sofía Fujimori Higuchi, hoy convertida por arte de birlibirloque en la abanderada de la "causa" de su padre preso, defensora de lo indefendible, lideresa de un grupo político desprestigiado a causa de su turbio pasado. Resulta irónico que, perdidas todas las "batallas" para lograr una amnistía para su progenitor, la doña pretende ahora fungir de "candidata a la presidencia del Perú" (sic) con el único propósito de indultar al autor de sus días, de llegar al poder. Y como en Chile su "causa" cayó por su propio peso, hoy sigue librando una batalla perdida, en un país ya curado de tanto odio y tanta violencia, amén de dictaduras y gobiernos tan corruptos como el que lideró el ahora preso ex mandatario. 22 
4- Hemeroteca de la Biblioteca Nacional del Perú.

5- Idem.

6- Publicado por el sitio monosymonadas.blogspot.com http:/ / monosymonadas.blogspot.com/2005/07/monos-y-monadas-033-del-11-deagosto.html (30/1/2010)

8- Caricatura: ¿ya se siente mejor, o quiere más papel?

http:/ / monosymonadas.blogspot.com/2005/07/monos-y-monadas-532-del-30-dejunio.html (30/1/2010)

9- Caricatura y artículo: Del Fujishock a la mermelada. Blog Monos y Monadas. http:/ / monosymonadas.blogspot.com/2005/07/del-fujishock-la-mermelada.html $(30 / 1 / 2010)$

10- Revista ¡No!, Año 1, \# 18, Lima 22 de junio de 1987 (Ejemplar conservado en la Biblioteca Nacional del Perú)

11- Los escandalosos sueldos de algunos funcionarios fujimoristas. Caricatura de Mario Moreno. http://www.terra.com.pe/humormoreno/ (2/11/2006 - Acceso Web desactivado)

12- Caricatura Bacimori - Blog La Nuez, de Javier Prado (1997) http:/ / lanuez.blogspot.com/2005/03/bacimori.html (1/3/2010)

13- Burrocracia. Dibujo de Molina. Diario El Comercio, 6/11/2007 
14- Alberto Fujimori en banquillo de los acusados. Viñeta de Carlín.

La República 9/11/2005

http:/ / arony.obolog.com/alberto-fujimori-banquillo-acusados-229742 (2/11/2006)

15- Salen corruptos. Publicado en el blog de Carlos Tovar (Carlincaturas), del diario La República, el 12/7/2005 (Acceso Web a esta imagen desactivado) http:/ / carlincaturas.blogspot.com/ (1/3/2010)

16- La chacana (quechua: tawa chakana, 'cuatro escaleras'), cruz cuadrada o cruz andina, es un símbolo milenario originario de los pueblos indígenas de los Andes centrales incluyendo a Bolivia, Chile, Ecuador y Perú. (...)Un partido político peruano, Perú Posible, cuyo lider, Alejandro Toledo (ex presidente de la república), ha utilizado la chakana para proyectar al pueblo una imagen de pertenencia al llamado Perú profundo. De hecho se conoce a este partido hasta hoy como el partido de la chakana. Versión de Wikipedia. http://es.wikipedia.org/wiki/Chacana $(1 / 3 / 2010)$

17- Caricatura del blog La Nuez, de Javier Prado (2006) http://blogs.elcomercio.pe/lanuez/ (1/3/2010 - acceso web a esta imagen desactivado)

18- Caricatura publicada en el blog La Nuez. (No hay acceso web a esta imagen bajada el 2 de noviembre de 2006)

19- Caricatura "La virgen de la dulzura", de Carlos Tovar "Carlín". (http://foros.paralax.com.mx - Nota: el enlace web a dicha ilustración está desactivado $(30 / 2 / 2010)$ 
20- Caricatura publicada en El Comercio, fechada a 3 de febrero de 2005 en su blog La Nuez.

21- Caricatura In Memoriam. La Nuez, 14 de julio de 2005

22- Artículo y caricatura: Los fujimoristas se preparan para defensa de su dictador. http:/ / pospost.blogspot.com/2007/06/los-fujimoristas-se-preparan-para.html $(2 / 3 / 2010)$

\section{Cuadro a. ¿Qué significa caricatura?}

Según la vigésima segunda edición del Diccionario de la Real Academia Española, el término "Caricatura" se aplica a un "Dibujo satírico en que se deforman las facciones y el aspecto de alguien", pero también es una "Obra de arte que ridiculiza o toma en broma el modelo que tiene por objeto", asimismo, es el adjetivo despectivo una "Obra que no alcanza a ser aquello que pretende." Por ende, se trata de una figura que puede ser distorsionada pero realista de lo que se pretende representar.

\section{El mico fiscalizador}

Fue una víctima más de la persecución política, no ya por parte de una dictadura aleve, sino por el lado de un gobierno supuestamente democrático (el de Alan García), que utilizó los sutiles hilos del poder para silenciarla. Pero la revista Monos y Monadas, como el Cid, todavía hace temblar a los rufianes de la política peruana, y a quienes hacen uso y abuso de un poder que se les da para servir a la sociedad, y no para aprovecharse de ella. 
Esta egregia publicación cómica fue, tal vez, la mejor creación del recordado poeta limeño Leónidas Yerovi (1881 - 1917), un intelectual de la generación de los 20s que un buen día no tuvo mejor idea que abrir una revista de humor, para burlarse de los políticos de su época, a los que detestaba, además de hacer una velada crítica social. Pero lo que nunca se imaginó el buen Leónidas era que su dilecto "hijo" iba a cumplir los cien años, un aniversario que fue objeto de reconocimiento no solo dentro del Perú. Monos y Monadas fue y es, qué duda cabe, la decana del humorismo político peruano, y no sin razón, a juzgar por su vigencia tan actual, llena de gracia y cundería, sus personajes desfilan por sus páginas amarillentas y coloridas, como los actores y actrices de la vida real, los protagonistas buenos y malos de nuestra historia republicana... allí están el generalito con sus galones y su sonrisa cínica, el ricachón con sombrero de copa, la damisela de copas, el dictador de turno con su corte de "ayayeros" 23, los parlamentarios de salón... nadie escapa a su mordacidad, y esto, tampoco los más singulares inquilinos de la vieja Lima: el canillita de la esquina, el bodeguero, el cantinero, la vendedora ambulante, los borrachitos de amanecida, el cura del barrio, el lechero, el mendigo, el provinciano recién bajado de la sierra, el sindicalista de postín, el hombre de negocios sin escrúpulos... para el ciudadano común esto suele ser una suerte de catarsis gráfica a sus frustraciones cotidianas, el hombre de la calle tantas veces desencantado por el "así es la vida".

En Monos y Monadas se puede recorrer prácticamente toda la historia del Perú del siglo pasado (S. XX). Para empezar, vamos a recorrer algunas las caricaturas de esta afamada publicación, cuyos dibujantes no hacen sino reflejar en papel el estado de ánimo del periodismo de turno ante las viscitudes de los personajes del alto (y no tan alto) plumero.

\subsection{Algunas portadas del devenir político-jocoso del Perú...}


(Nota de Redacción: se ha considerado conveniente colocar bajo algunas de las siguientes imágenes sus leyendas originales en cursiva) 


\section{MONOS Y MONADAS}

\section{QUINCENARIO FESTIVO Y DE CARICATURAS}

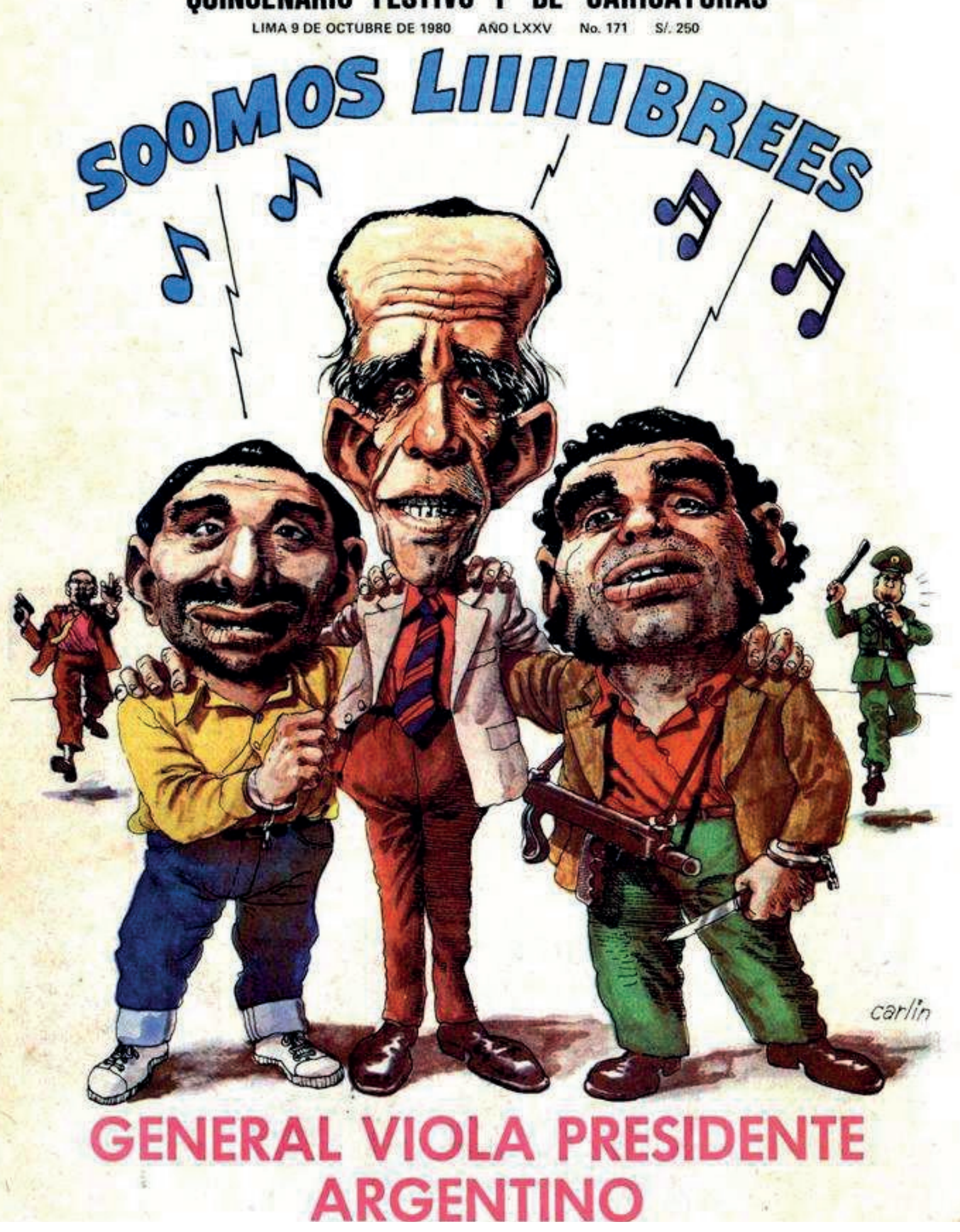


Monos y Monadas \# 171, julio de 2005, cuando se celebraban lasfiestas patrias de aquel año -en pleno régimen de Alejandro Toledo-, inspirado en esta caricatura de portada de 1980, el autor de la leyenda de esta ilustración -publicada en su blog-, quiso burlarse de los escandalosos excesos y dispendios (a costa del erario público) que por esos días cometía, con el mayor desparpajo, el entonces presidente Alejandro Toledo (2001-2006), con la complicidad de sus cercanos allegados, todo ello a espaldas de la opinión pública peruana. El texto que sigue abajo, de puño y letra del ex director de esta notable publicación impresa, Nicolás Yerovi, convertido ahora en bloguero, ridiculiza de esta manera la corrupción y la frivolidad de este increíble presidente peruano, y las inmoralidades de su entorno, y lo hace re-inventando la célebre canción de la canta-autora Chabuca Granda, La Flor de la Canela, donde ha sustituido adrede algunas palabras y líneas de la letra original de esta composición, con el objeto de parodiar a estos singulares integrantes de la corte palaciega toledista, tales como el ex asesor César Almeyda, al parecer el "favorito" de la esposa de Toledo, Eliane Karp -la entonces petulante "primera dama" - , y el ex ministro de Comercio Exterior y Turismo, Alfredo Ferrero, entre otros prójimos que acabaron convertidos en los "ayayeros" 23 de turno de un régimen donde imperó la vulgaridad y la chabacanería. He aquí, pues, el texto original de esta graciosa leyenda, tal como ha sido redactada en la Web de Monos y Monadas.

No hay mejor manera de celebrar las Fiestas Patrias del Perú que entonando ese hermoso vals de Chabuco Almeyda, un pata que está en caneyda, La Flor de la Caneyda. (en alusión a César Almeyda, dixit... N. de R)

Por la versión, Nicolás Yerovi.

Ruégase al patriótico lector cantar la célebre melodía con la siguiente letra:

\section{LA FLOR DE LA CANEYDA}

Déjame que te cuente, limeyda, 
cómo se fue Toleido a la meyda,

con Ferreiro, Pacheico y Oliveyda,

el pasajero más frecuente de Iberya.

Parientes borrachines, sobrinos violadores

Toleido se paseaiba y a la China viajaiba,

Hermanos pirañosos, cuñaidas coimeadoras

Que un pollo te cobraiban si tu las contrataibas.

Déjame que te cuente, limeyda,

ay, deja que te diga, qué vida, tan regalayda,

la vida que Toleido se dayba,

mientras todos los días, la mafia,

jueces coimeaiba.
Al fugar se establecían
En Chile y en la Argentina
En Suiza y en la Florida
Los rateros nos vivían.
Y uno aquí se las buscaiba,
Pero chamba no encontraiba,
Día y noche en la embajaida
Una visa limosneaiba.

Y recueyda que...

Parientes borrachines, sobrinos violadores

Toleido se paseaiba y aquí nada pasaiba,

Hermanos pirañosos, cuñaidas coimeadoras

Que un pollo te cobraiban si tu las contrataibas. 
Parientes borrachines, sobrinos violadores

Toleido se paseaiba y aquí nada pasaiba,

Hermanos pirañosos, cuñaidas coimeadoras

Que un pollo te cobraiban si tu las contrataibas.24 


\section{MONOS Y MONADAS} QUINCENARIO FESTIVO Y DE CARICATURAS

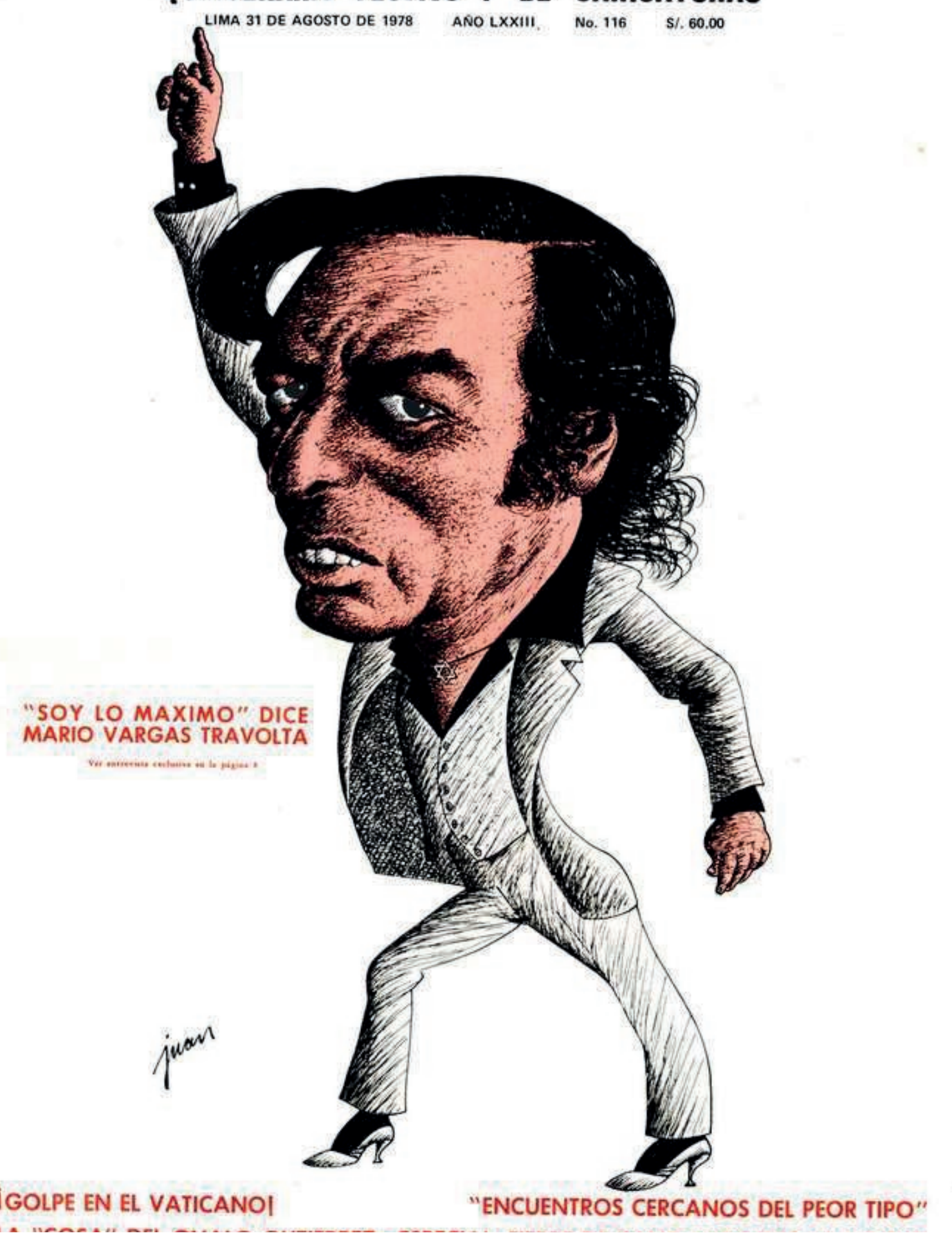


Monos y Monadas \#116 del 31 d Agosto de 1978, caratula dibujada por el reconocido historietista del "Cuy", "Love Story" y "Pobre Diablo" Juan Acevedo. El autor del dibujo ironiza a Mario Vargas Llosa, un escritor disidente en pleno tiempo de la dictadura militar del general Juan Velasco Alvarado, presidente de facto entre 1968 y 1975, año en que fue depuesto por un colega suyo. 25 

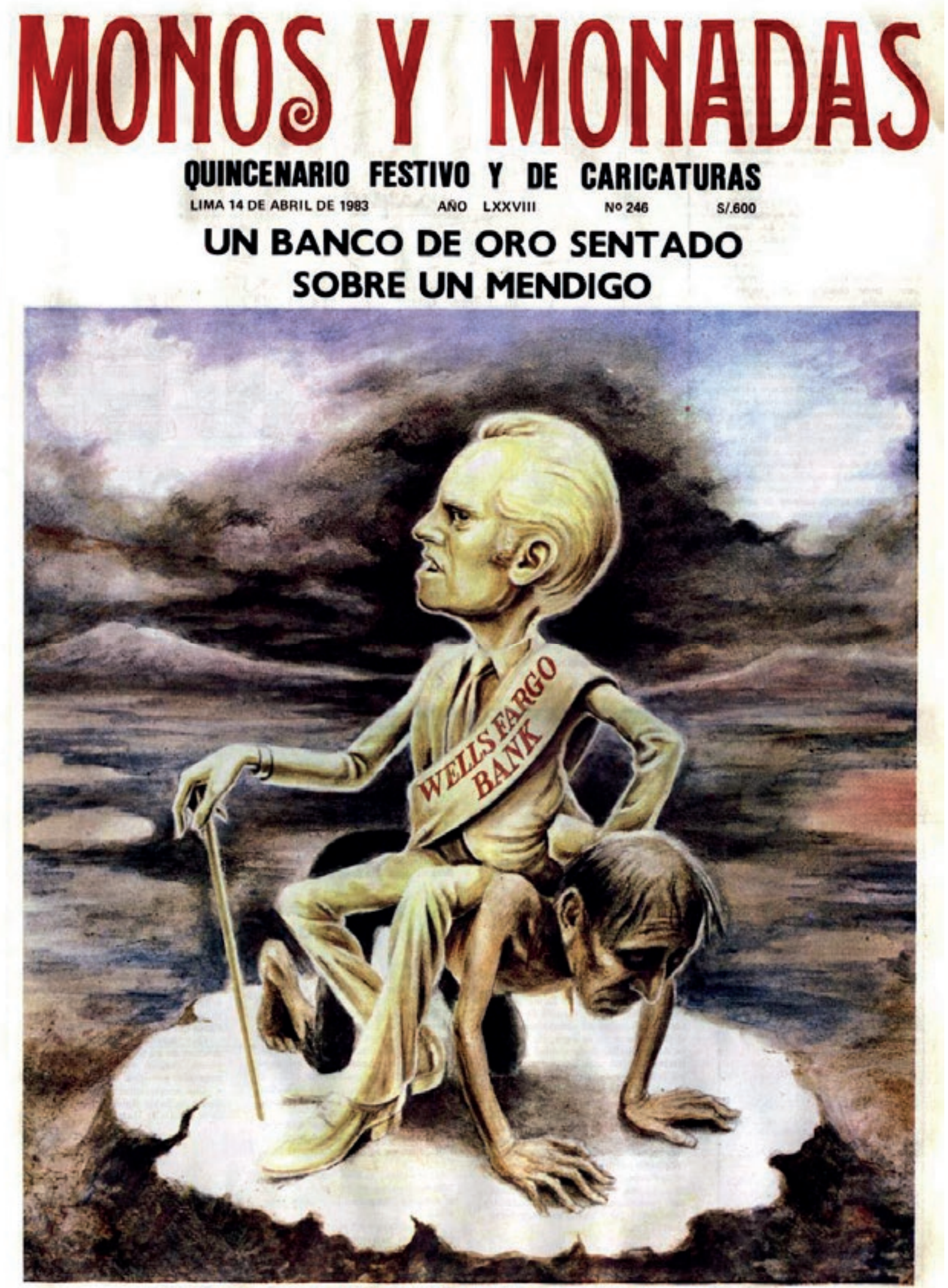

PRIMICIA: DECLARACION JURADA DE LUIS BERTELLO• 
Monos y Monadas \#246, lima 14 de abril 1983, Ale. Como parodiando aquella célebre frase del gran naturalista italiano Antonio Raimondi ("El Perú es un mendigo sentado en un banco de oro"), el conocido caricaturista Ale, que salió de las canteras de esta notable revista, hace notar la absurda condición de un país que, teniéndolo todo, no tiene nada. Esta carátula de Monos y Monadas fue de verdad premonitoria, cuando en aquellos días era presidente del Perú el arquitecto Fernando Belaunde Terry, en su segundo mandato (1980-1985). ¡Quién se iba a imaginar que el buen Ale estaba "prediciendo" con sus hábiles trazos de carboncillo al Perú del primer gobierno de Alan García (1985-1990), cuando, efectivamente, la sociedad peruana iba a ser el mendigo debajo del banco de oro, jen medio de la híper- inflación que nos hundió por completo! 26

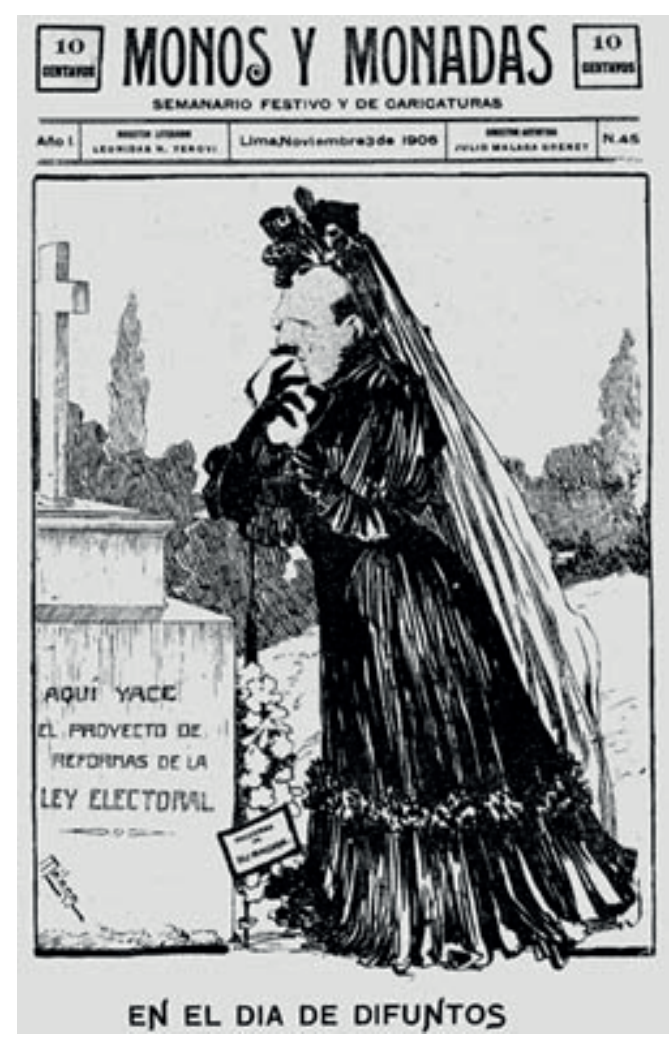

Monos y Monadas \# 46, Lima, Noviembre 3 de 1906. Málaga Grenet, fue tal vez uno de los mejores ilustradores y caricaturistas que tuvo el Perú; este notable dibujante, 
que laboró también en la recordada revista Variedades, en los años 20s, ilustró una de las primeras carátulas de la publicación que fundara Leónidas Yerovi en ese mismo año; aquí vemos una parodia gráfica que critica la ineptitud de los entonces padres de la patria, es decir, los congresistas de ese entonces. Y qué mejor ocasión como aquella, coincidiendo con el Día de Difuntos, para retratar a una viuda llorando ante una lápida que ostentaba el siguiente rótulo: Aquí yace el Proyecto de Reformas de Ley Electoral, es decir, como todavía sucede con tantas leyes de vital importancia para el país, que duermen el sueño de los justos porque sencillamente a los señores congresistas no les da la gana cumplir con su deber de legisladores, el Derecho al Sufragio Universal tuvo que esperar cinco décadas (1956) para ser por fin una realidad. 


\section{MONOS Y MONADAS}

\section{QUINGENARIO FESTIVO Y DE CARICATURAS}

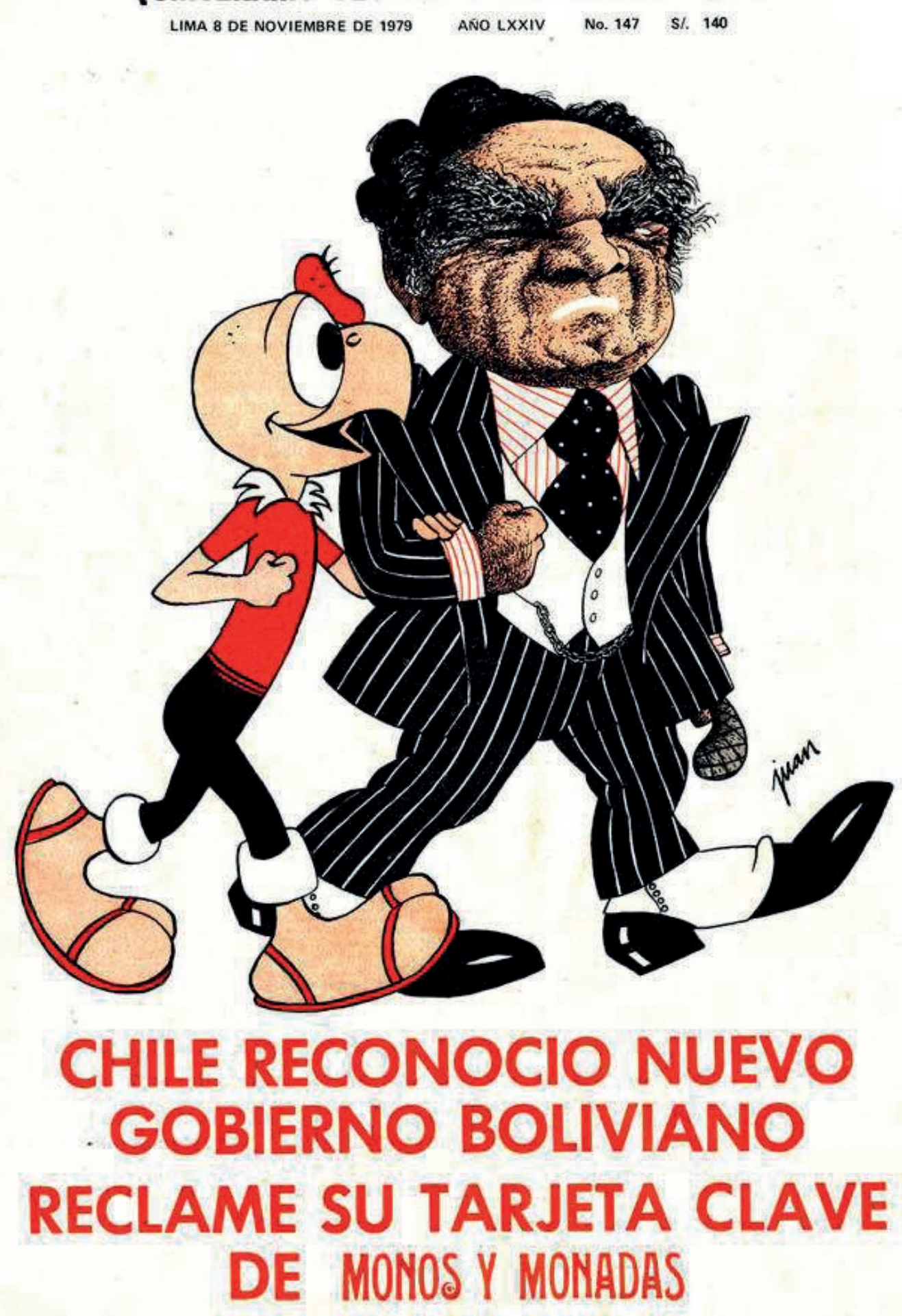


Monos y Monadas \#147 del 8 de Noviembre de 1979 (que fue declarado "Año de los Héroes de la Guerra del Pacífico"), caratula dibujada por Juan Acevedo donde aparece Villanueva del Campo (Apra) y Condorito.

Sería bueno que en estos tiempos donde a Chile poco le falta por declarar como nombre de origen la palabra Peru, cojamos al plumifero y le EXIJAMOS UNA EXPLICACION.

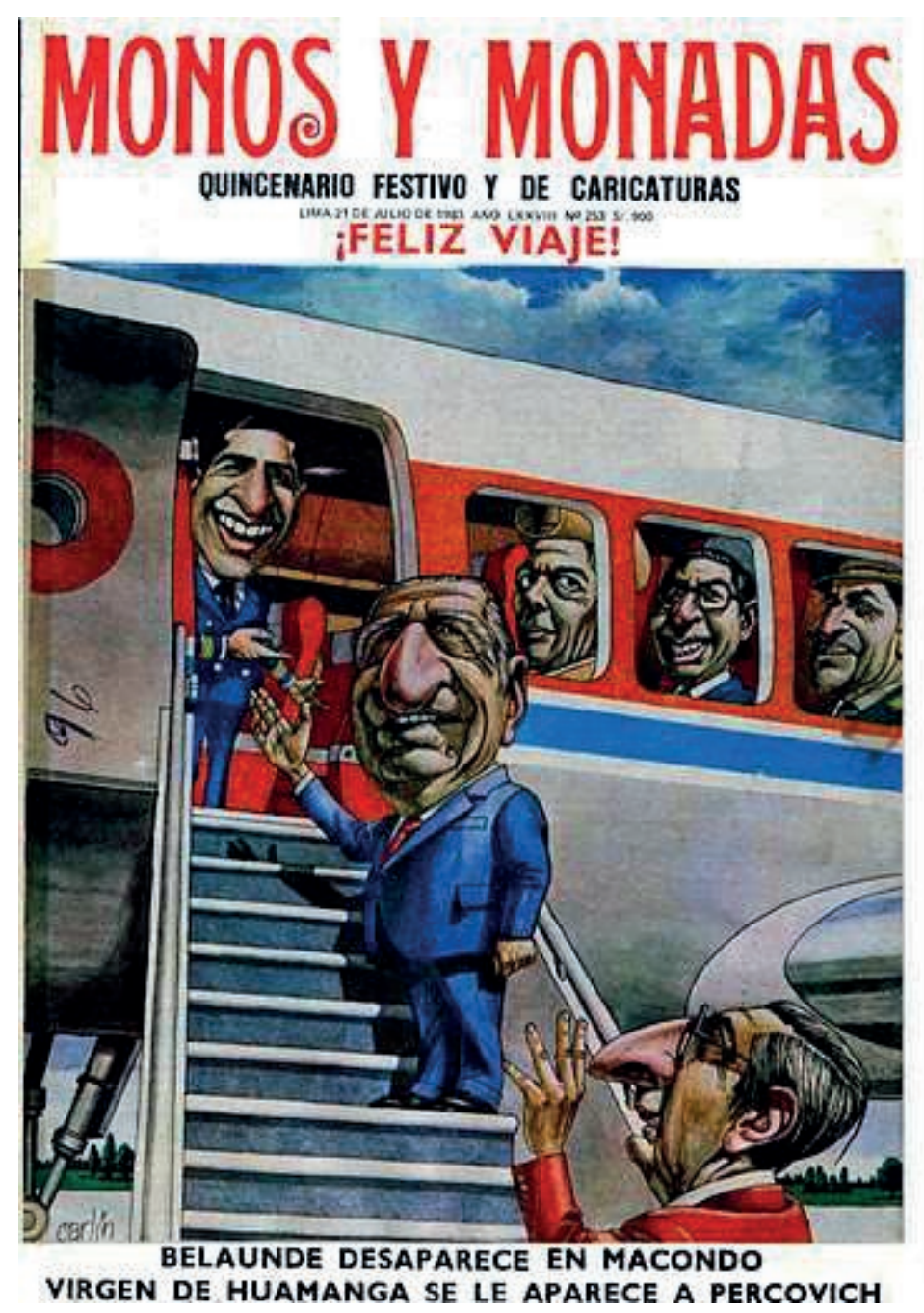

Monos y Monadas \#253, lima 21 de julio de 1983. En esta ilustración, el entonces novel Carlín satirizó a los políticos-viajeros, que se aprovechan del poder de turno para darse sus escapaditas allende las fronteras, nada menos que en el avión 
presidencial. Caras conocidas vemos aquí, de personajes de los que ya nadie se acuerda: son los ministros y allegados del entonces presidente Fernando Belaúnde Terry durante su segundo mandato, en uno de sus constantes "tours turísticos" a costa del erario público, que fueron muy criticados por la prensa y la opinión pública, debido a que tales viajes eran de placer y no de trabajo -como todo el país pensaba-, ello con el agravante de que tales "excursiones pagadas por el Estado" solían terminar en el lugar menos pensado, donde no se acataba, precisamente, el deber de cumplir con la labor encomendada por quienes votaron por ellos.

23- Ayayero/s. Esta acepción es un coloquialismo muy propio del Perú, que puede significar: prepotente, abusivo; también es sinónimo de bullanguero, escandaloso. Por eso se dice: "por ayayero tuvo que presentarse ante el alto-tombo (policía - N. de R) después de la batidca..." Definición del Diccionario de Argot Limeño o Jerga Criolla del Perú, de Guillermo E. Bendezu Neyra, ya citado.

24- Blog de Monos y Monadas http://monosymonadas.blogspot.com/ Archivo: julio $2005(1 / 3 / 2010)$

25- http://monosymonadas.blogspot.com/2005/11/mvll.html Archivo: noviembre $2005(1 / 3 / 2010)$

26- http:// monosymonadas.blogspot.com/2009/06/ un-banco-de-oro-sentado-sobreun.html $(1 / 3 / 2010)$

\section{Sabía Ud, que...}


... prácticamente casi todos los dibujantes y caricaturistas sobre temas de humor político actuales, los más veteranos sobre todo, han pasado por las páginas de Monos y Monadas.

...se piensa que el cronista mestizo Felipe Huamán Poma de Ayala, el autor de “Nueva Corónica y Buen Gobierno" (1615), fue el primer caricaturista y dibujante crítico en la historia americana.

... para algunos historiadores, el pintor inglés William Hogarth (1697-1764), ha sido considerado el padre de la caricatura política en Europa, aunque otras versiones señalan que este arte nació en el siglo XVI, en Bolonia, en el atelier de los Carracci, una familia de pintores italianos.

...el escritor peruano Abraham Valdelomar, el autor de la novela costumbrista El Caballero Carmelo (1918), fue también un gran dibujante, sobre todo en el campo del humor político. Así lo atestiguan sus mordaces caricaturas que publicó en la revista Monos y Monadas, sobre personajes como Augusto B. Leguía, cuando este era ministro, quien, a la postre, llegaría a la presidencia del Perú.

\section{Recortes de prensa}

\subsection{La Política es un Dibujo}

Artículo de Jerónimo Pimentel, escrito en Caretas, Edición \# 1662, 22 de marzo de 200128

Versiones y diversiones de los caricaturistas sobre la contienda electoral.

El mejor humor es el que te

hace reír cinco segundos

$\mathrm{y}$ te hace pensar diez minutos.

Oscar Wilde. 


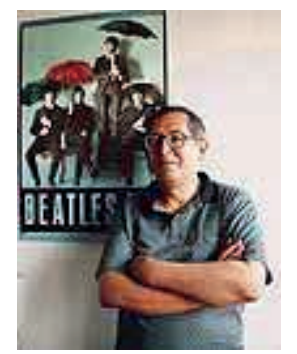

El enigmático Heduardo, escondido en algún lugar del sur bajo la estrella de los fab four.

FLAMIGERA, ambigua, explicativa, de combate. Punzocortante, directa, verbal, ideológica. Hiriente, bivalente, gráfica, detonante. La caricatura política es la forma en la que un cerebro artístico, intelectual y periodístico, por medio de un proceso no del todo consciente, se encarga de procesar y sintetizar información para volcarla en un cuadrilátero en el que, a través de trazos y/o palabras, generará una sacada de vuelta a la realidad que produce, en el mejor de los casos, una sonrisa -mental o sardónica- que dejará al lector una pequeña satisfacción, nuevo punto de vista o frustrante derrumbe de expectativas creadas.

Requisitos y condicionamientos: primero romper los mitos, no es necesario ser un buen dibujante, al menos eso afirma Heduardo Rodríguez, caricaturista principal de CARETAS con Heduardo en su Tinta y colaborador de Gestión, quien no se considera como tal: "me considero un periodista, un columnista de opinión" afirma, y en esto último coinciden todos. La caricatura política es una actividad crítica desde una posición particular. La objetividad no existe, y menos en un género interpretativo. En periodismo no, al menos, los norteamericanos lo descubrieron hace décadas (pero queda la veracidad, reclaman los melancólicos). Entonces uno debe atenerse a lo que hay: empaparse de realidad y empezar a descubrir lo que Alfredo Marcos, caricaturista de La República, llama las contradicciones del ser humano. Él mismo continúa: "en la caricatura tú conviertes la tragedia o la crisis en humor, y lo 
expresas de una manera distinta". Heduardo no acepta preguntas conceptuales, pero con una sonrisa sentencia que "son los caricaturistas políticos los que van minando esa fuerza de dioses o salvadores de los que vienen a gobernar, nuestro aporte es quitar el endiosamiento que tienen los líderes".

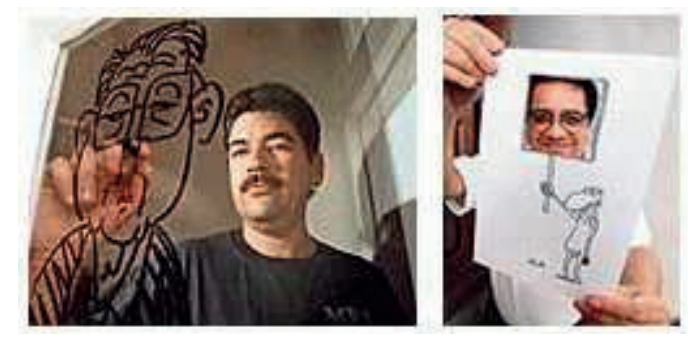

Mario Molina dibujando a su fugitivo favorito en vidrio. Cuando el humor entra por la puerta, la tragedia se va por la ventana. Derecha: El caricaturista Alfredo Marcos embanderado por una de sus propias criaturas, el calato.

Lo otro es el carácter eminentemente crítico (y aguafiestero) de los caricaturistas. Sobre todo en una campaña política, en la que las sensibilidades y posiciones traslucen simpatías y disgustos que se pueden confundir con adhesiones o mala leche. Mario Molina, ilustrador y caricaturista de CARETAS y colaborador de Liberación, enfila: "no concibo un humor político que sea laudatorio o pasado por agua tibia, no tiene sentido, sería ilustración pero no caricatura". Heduardo toma la posta: "nosotros nos alegramos cuando alguien hace algo bueno, pero eso no te motiva para hacer una caricatura, porque la caricatura política es tomarle el pelo a alguien". Alfredo difiere: "nosotros elegimos a nuestros adversarios, contra ellos nos enfrentamos, no podemos usar las mismas armas con las que consideramos a nuestros amigos, aliados o simpatizantes... es un asunto de opciones". Molina insiste: "tú tienes tu opción y criticas desde esa opción a todos..., todos tienen algo desde donde se les puede coger". Alfredo espera: "los caricaturistas deberíamos estar aislados, en mi caso no lo he podido hacer, es al revés, yo soy amigo de muchos políticos, siempre las mejores caricaturas son de gente que no conozco". Resumen: 
libertad plena. Por eso, mientras Alfredo prefiere no esconder su simpatía toledista, Heduardo opta por navegar por aguas libres de compromisos políticos.

¿Situaciones anómalas? Respetar el tiempo de gracia de un Presidente recién nombrado, estar de acuerdo con algún mandatario, y la peor de todas (y aún inédita para felicidad de ellos y tragedia de los demás peruanos): que no suceda nada. Pero, como decía algún galo de Astérix, de ésos que hicieron que Molina descubra temprano su vocación, "eso no va a pasar mañana". Total, apunta Marcos, "el humor peruano está nutrido, como el valse criollo, de tragedia, de comedia, de alegría, a pesar de todo, y de muertes y renaceres diarios". Al fin y al cabo vivimos, para bien o para mal, en el país de las maravillas, donde convergen viejas pitucas y dignos calatos, dirigidos intermitentemente por hombres que no pueden irse. Aunque al final todos se van, por más que la canción anuncie su retorno. (Jerónimo Pimentel).

\subsubsection{El Miguel Ángel de Vladimiro}

Miguel Ángel Mesías, caricaturista de Expreso, fue requerido por CARETAS para la elaboración de la siguiente nota. Sin embargo, Mesías se negó a ella aduciendo la realización de un viaje. A continuación la declaración de Vladimiro Montesinos sobre su injerencia en el humorista.

Transcripción del vídeo No 1792. Diálogo del general Villanueva, almirante Ibárcena, general Bello y Vladimiro Montesinos.

Montesinos: "Además con los periódicos hemos hecho, uff, unas caricaturas hoy día en el Expreso. Pero fíjense en la ventaja del manejo de los medios, si no manejamos los medios, carajo".

\subsubsection{Confesiones de parte}

5.1.2.1 Candidatos bajo la óptica de espinosos caricaturistas. 
Heduardo: No me ha gustado como ha reaccionado con este asunto de la prueba del $\mathrm{ADN}$. Al margen de esto, noto ciertas tendencias autoritarias en él. Le falta sentido del humor. No me gusta la ceremonia de la bandera, es totalmente actuada, impostada.

Alfredo: Toledo tiene un lenguaje popular, yo lo veo como un tipo que sabe manejarse. En escenarios distintos, uno tiene que actuar de una manera en uno y de otra en otro. Toledo va a hacer un gobierno para los pobres porque ha sido pobre.

Molina: Hay dos cosas en las que está fallando. Una es que dice una cosa un día y después cambia de opinión, habla de acuerdo al auditorio. Lo otro es lo de la hija, nadie puede afirmar a ciencia cierta que es su hija, pero yo creo que debería hacerse la prueba. En caso de ser el padre yo dudo que eso le reste votos.

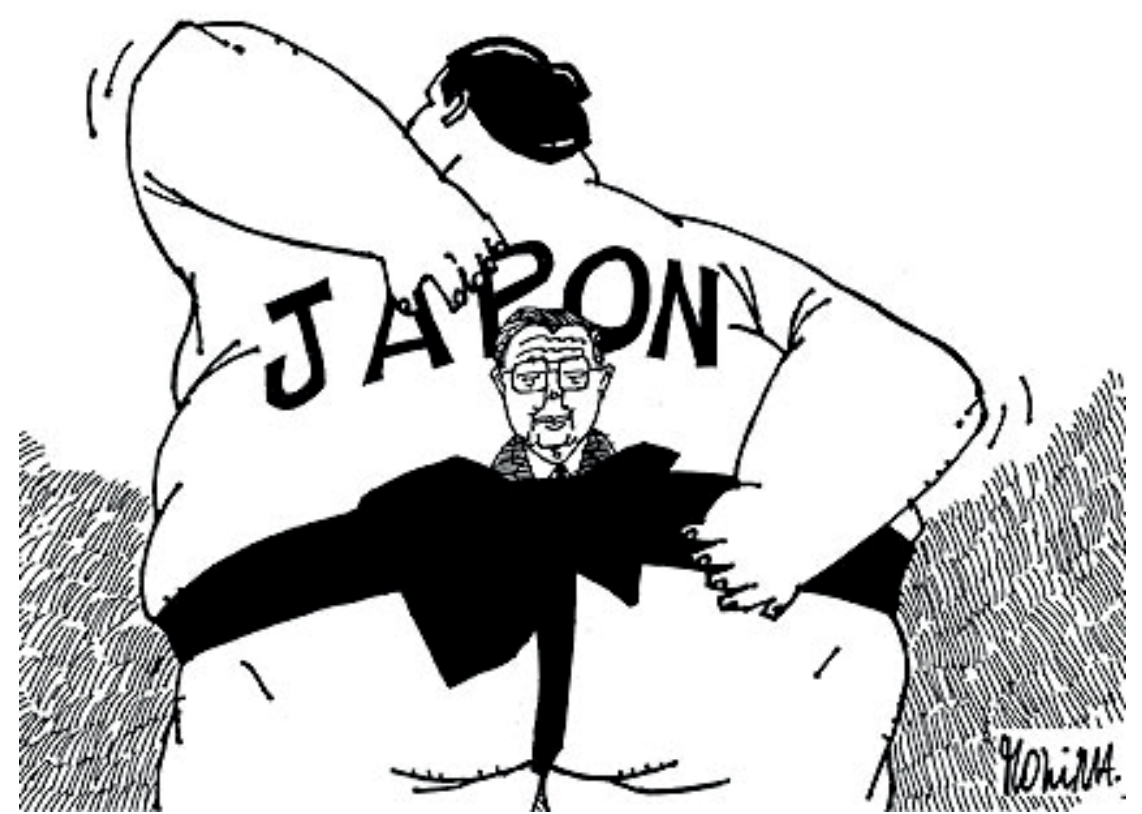

Jocosa caricatura que retrata al entonces prófugo ex presidente Alberto Fujimori, escondido tras el trasero del Japón para huir de la justicia peruana, como da a entender su autor, Heduardo. (Nota de Vivat Academia) 


\subsubsection{Sobre Lourdes Flores}

Heduardo: Lo malo de Lourdes Flores es que está rodeada de gente sospechosa, hay una serie de fujimoristas que podrían estar arrepentidos, pero que en una crisis podrían volver a las andadas. Me parece mejor candidata que Toledo, pero como siempre no es sólo la candidata, sino el programa, las personas que la rodean. (...). No tiene mucho olfato para las cosas que vienen más adelante.

Alfredo: Lo importante es saber que uno es un grano de arena, lo importante es ser un grano de arena a favor, no en contra, para el desarrollo de la humanidad. (...). Yo creo que (Lourdes Flores) es un grano en contra, a pesar de ella de repente. Creo que es representativa del continuismo político y económico.

Molina: El temor que hay con ella es que el manejo de la economía sea más o menos similar al de Fujimori.

\subsubsection{Sobre Alán García}

Heduardo: Yo creo que Alan no es un tipo corrompido, hubo una campaña terrible en su contra pero al final no se le probó gran cosa. Él está en ese grupo de personajes que quieren pasar a la historia como políticos, su ambición es política, quiere realizarse, quizá en algún momento ser el segundo Haya.

Alfredo: Alan García es una persona que tiene muchos méritos personales, yo creo que ha cometido muchos errores, pero nadie puede ser condenado por errores.

Molina: Alan no tiene chance, el pata tuvo su oportunidad. Tiene una presencia importante pero no le basta. 
28- http://www.caretas.com.pe/2001/1662/articulos/humoristas.phtml (1/3/2010)

\section{Tres caricaturas peruanas más... del diario El Comercio}



Patrimonio arqueológico al mejor postor. Molina se hizo eco del escándalo que estalló en mayo de 2007, cuando se descubrió que hasta personalidades de confianza del actual régimen lucraban sacando del país valiosas piezas de cerámica preincaica para venderlas a las casas de remate de objetos de valor en Estados Unicos y en Europa. Caricatura publicada en la sección "Humor Profano" de El Comercio, 17/5/2007 pp. a4 29 


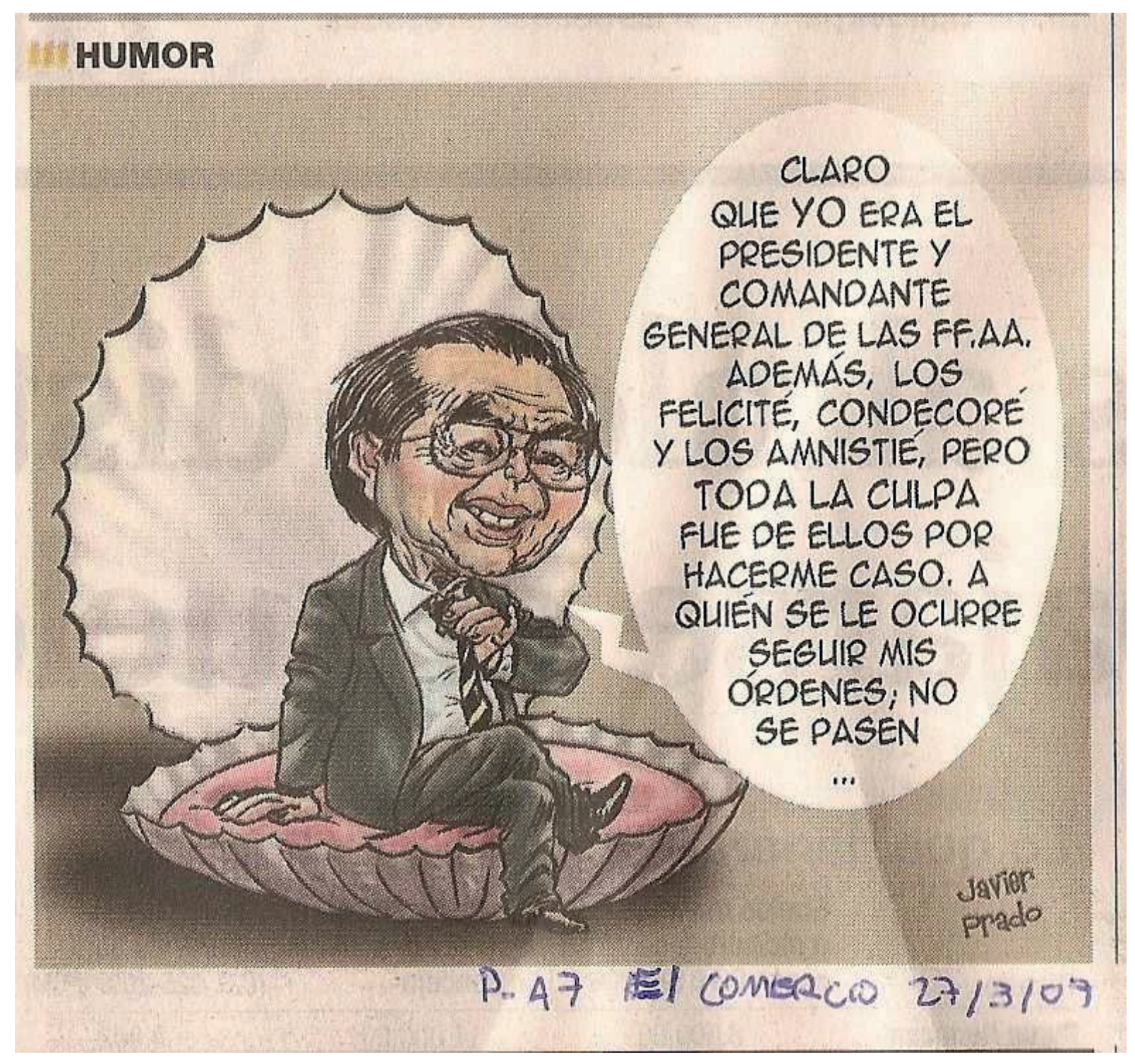

Un molusco para Fujimori. Cuando el ex presidente Alberto Fujimori estaba siendo procesado en Chile para tramitar su extradición a Lima, causaron revuelo estas cínicas declaraciones suyas, las mismas que fueron recogidas por el dibujante Molina en está ácida caricatura, que de verdad lo pone en el lugar donde le correspondía, como un representante más de la "concha" peruana 30, como solemos decir por estos lares. Ilustración de El Comercio, en “Humor Profano", 23/3/2007 pp. a7 


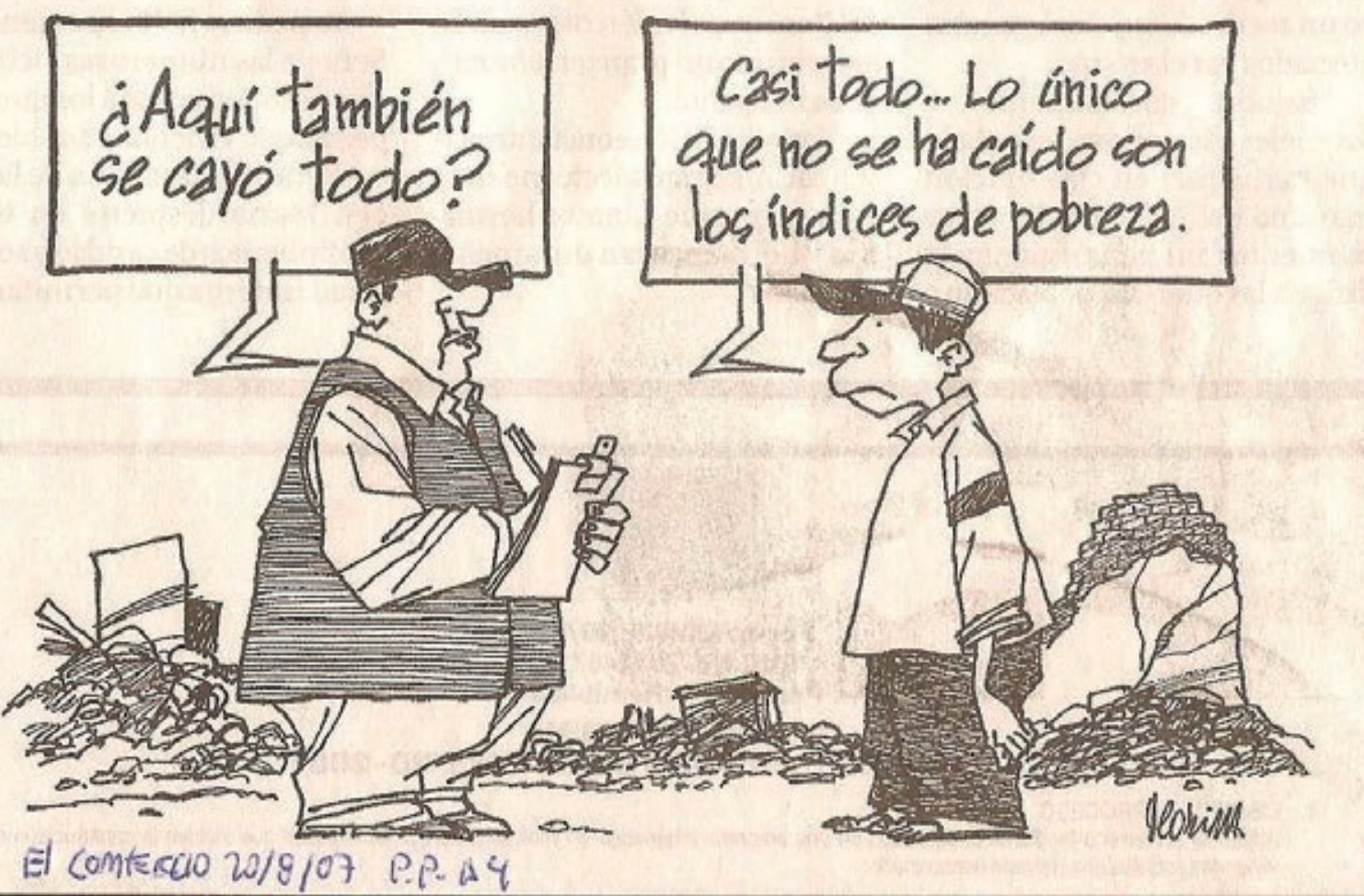

Crueles ironías de la demagogia... Esta caricatura de Molina refleja lo que puede hacer la sinvergüencería de nuestros políticos, cuando tras el devastador terremoto del 15 de agosto de 2007, en el sur peruano, afirmaron que iban a "reconstruir Pisco", la ciudad que mayor daño sufrió con el sismo. En uno de los desatinos a los que ya nos tiene acostumbrados la burocracia limeña, mentalmente centralizada, se hizo un sondeo de la popularidad del presidente Alan García tras la mala política adoptada por el gobierno para socorrer a los damnificados de esta contingencia natural... y cuando llegaron a la entonces arruinada Pisco -que aún espera que San Juan baje el dedo y conmueva a papito gobierno para que, de una vez por todas, se ponga las pilas y asuma su ofrecimiento oficial de reconstruir la ciudad-, esta es la respuesta que los encuestadores recibieron. Ilustración de El Comercio, en "Humor Profano", 20/8/2007 pp. a4 
29- Ilustraciones de la sección Humor Profano, diario El Comercio de varias fechas.

30- ...desvergüenza, desfachatez, inescrupulosidad (...) Definición de Guillermo E, Bendezu Neyra. Op. Cit.

\section{Un sorbo de humor político castizo...}

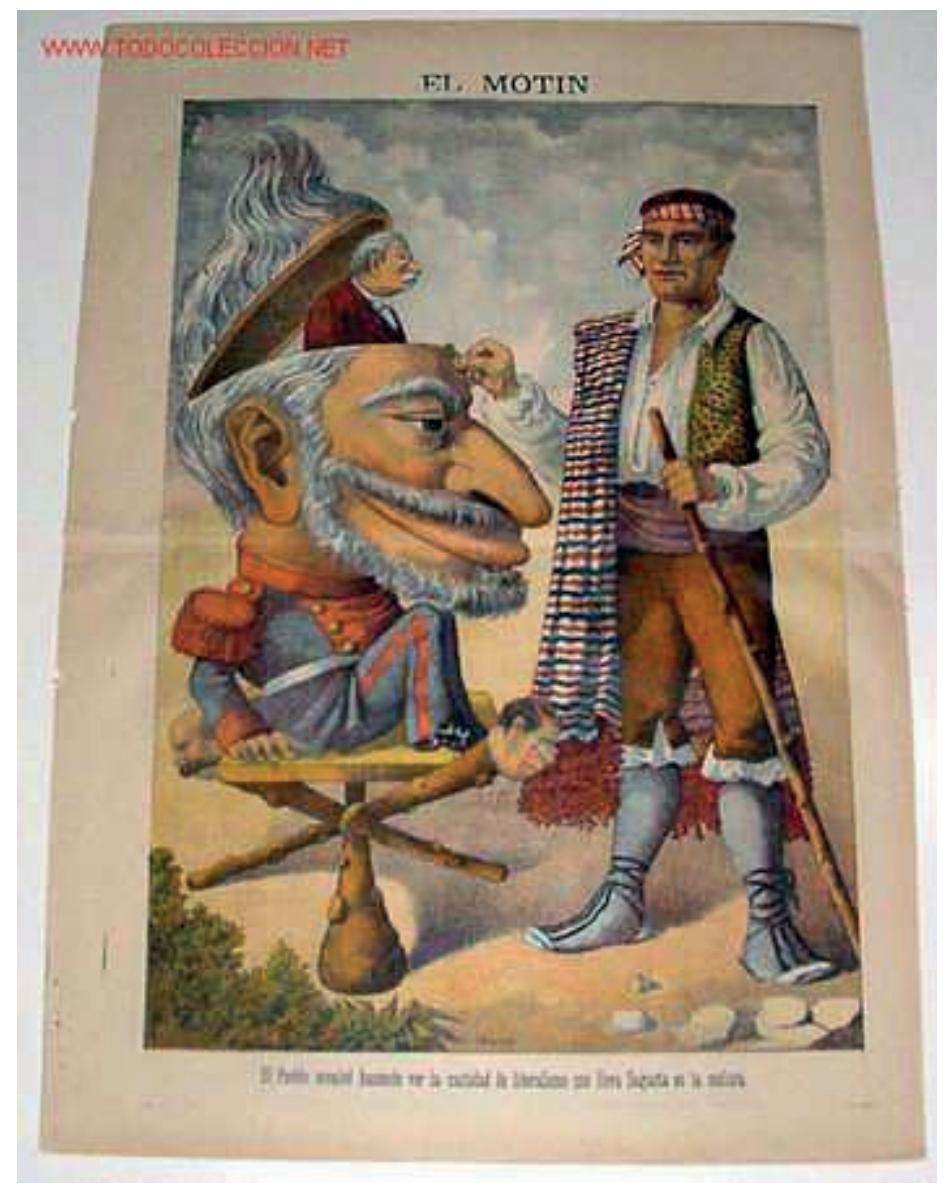

El Motín. Cartel caricaturesco, Periódico Libertario, 188731 


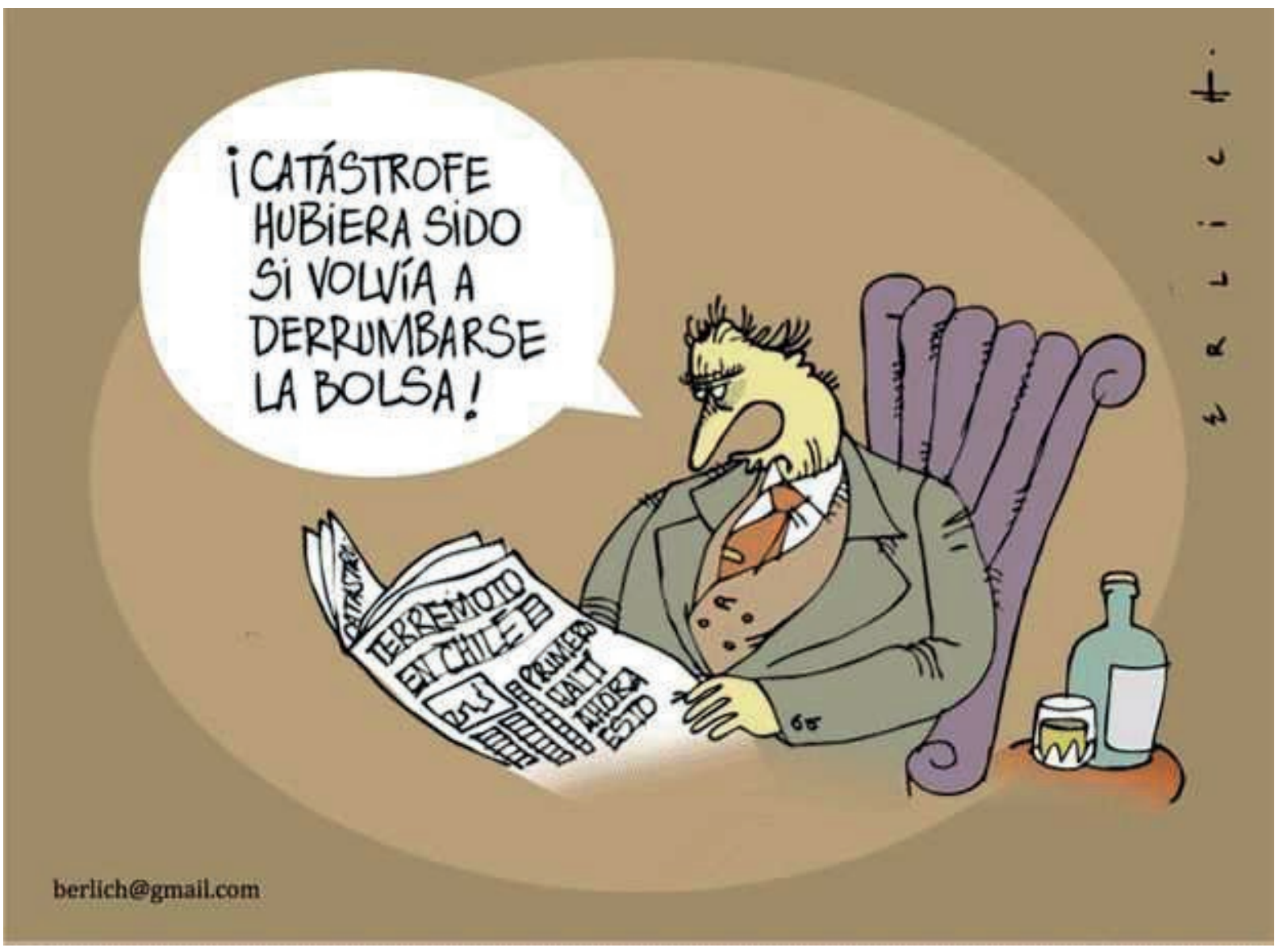

Caricatura de Erlich que satiriza el temor por la caída de las bolsas. 32

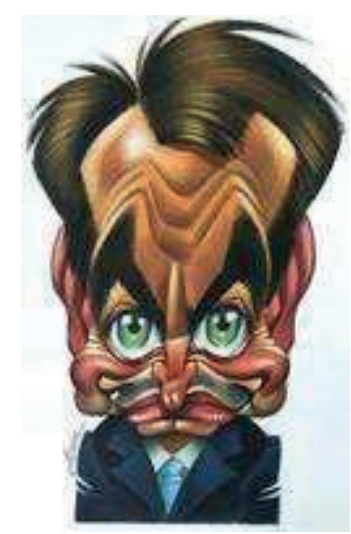

Caricatura de José Luís Rodríguez Zapatero. Dibujo de Vizcarra. 33 
31- Ilustración humorística de época tomada del sitio http://www.todocoleccion.net/ (23 de diciembre de 2007 - Nota: el enlace web a este sitio han sido, aparentemente, desactivado o ya no existe)

32- Publicado en Viñetas de El País, Madrid, 2 de marzo de 2010 http:/ / www.elpais.com/vineta/?d_date=20100302\&autor=Erlich\&anchor=elpporop ivin\&xref=20100302elpepuvin_2\&type=Tes\&k=Erlich $(2 / 3 / 2010)$

33- Portal Web de la revista humorística El Jueves http://www.eljueves.es/ $(1 / 3 / 2010)$

\section{Y para terminar, una "refrescante" parodia de Bush y Obama...}

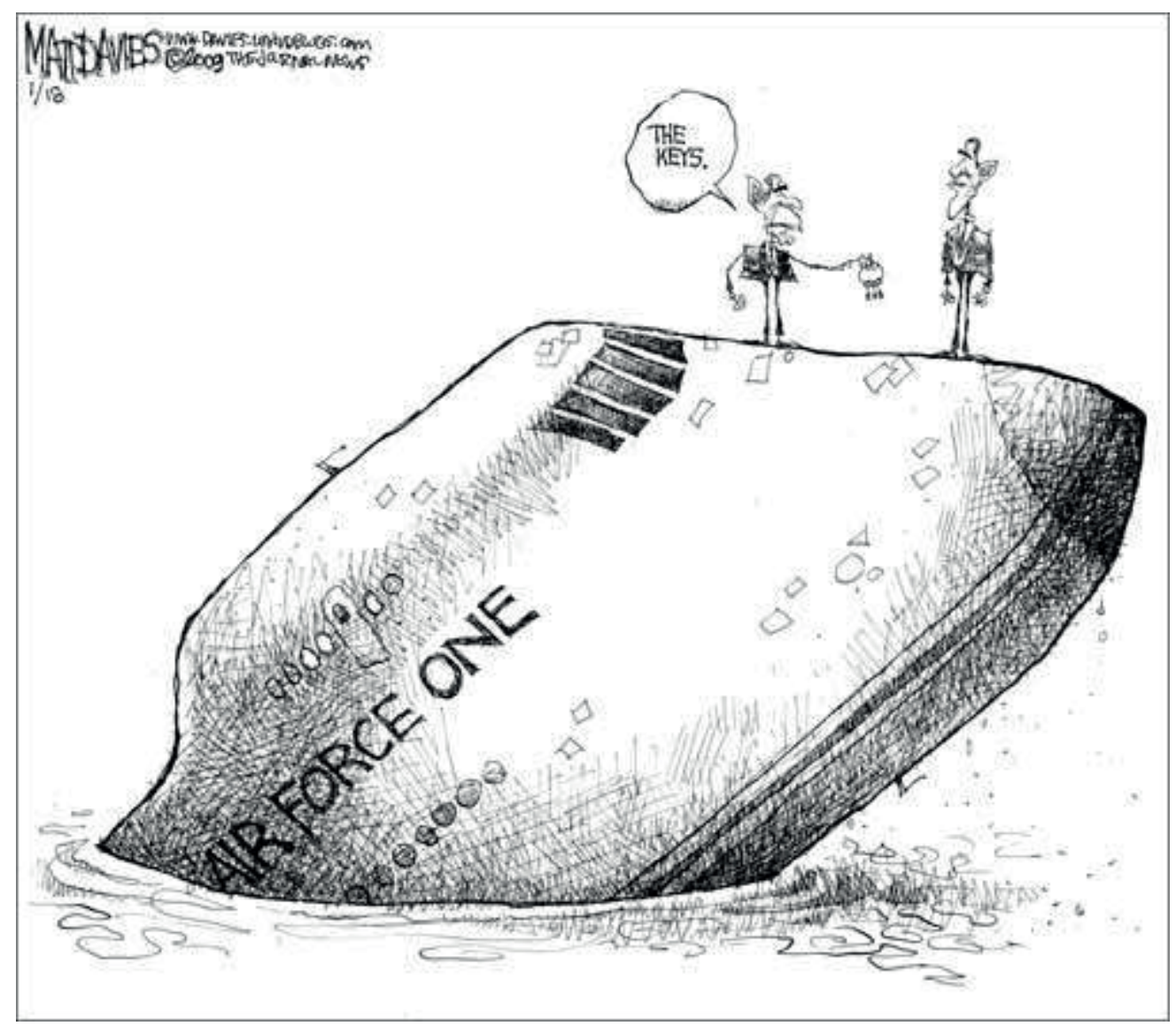


Caricatura política representando el cambio de mando de George W. Bush a Barack Obama, en Estados Unidos. En ella, George W. Bush le dice a Obama: "Las llaves" ("The keys"). El avión sumergido es el Air Force One, el avión presidencial de Estados Unidos. George W. Bush salió de la Casa Blanca el 20 de Enero de 2009, después de un gobierno juzgado unánimemente como desastroso, y con los peores índices de popularidad en toda la historia de Estados Unidos. Caricatura publicada en el Blog “Milenoscopio"34

34- Blog Milenoscopio http://milenioscopio.blogspot.com/2009_02_01_archive.html $(1 / 3 / 2010)$

\section{Fuentes}

Nota: A modo de referencia sobre las fuentes de esta información, señalamos entre paréntesis la fecha de la última lectura de los hipervínculos consultados para el presente capítulo: $(28 / 2 / 2010)$

Blog de la revista Monos y Monadas.

http:/ / monosymonadas.blogspot.com/

Caricatura - Wikipedia.

http:/ / es.wikipedia.org/wiki/Caricatura

Caricatura Política (sobre periodismo iconográfico)

http://www.ull.es/publicaciones/latina/2001/latina45diciembre/4506abreu.htm

Carlincaturas - Blog de Carlos Tovar (Carlín)

http:/ / carlincaturas.blogspot.com/

Cronología de la Historieta Peruana

http://www.kingdomcomics.org/historieta_peruana.html 
El grabado peruano durante el siglo XIX, capítulo 1 (documento pdf)

http://sisbib.unmsm.edu.pe/bibvirtualdata/libros/Historia/Grabado_Peru/cap1.p $\mathrm{df}$

El Otorongo - Blog del Suplemento cómico-político del diario Perú21

http://blogs.peru21.pe/elotorongo/

El Útero de Marita, blog de noticias y humor político.

http://utero.pe/

Francisco González Gamarra, dibujante peruano.

http://www.fgonzalezgamarra.org.pe/caric.html

Heduardo (Heduardo Rodríguez)

http://blogs.peru21.pe/heduardo/

Humor Moreno - Caricatura Peruana. Blog de Javier Moreno.

http://www.terra.com.pe/humormoreno/

La Caricatura Política en el Perú - Julio Málaga Grenet y otros (documento pdf) http://www.cybertesis.edu.pe/sisbib/2005/luna_mo/pdf/luna_mo-TH.5.pdf

La Caricatura Política en el Perú - Revista Identidades del diario El Peruano.

http://www.elperuano.com.pe/identidades/94/resenas.asp

La Caricatura Política de Bagaria

http://www.peatom.info/la-llave/17982/cuenca-exhibe-500-caricaturas-de-

bagaria/

La Nuez, el blog de Javier Prado.

http://lanuez.blogspot.com/

Juan Demetrio Acevedo Fernández de Paredes - Dibujante peruano - Artículo en Wikipedia.

http://es.wikipedia.org/wiki/Juan_Demetrio_Acevedo_Fern\%C3\%A1ndez_de_Par edes

Vinatea Rinoso - Revista Mundial.

http://vinatea.perucultural.org.pe/revis2.htm

Vizcarra, un notable caricaturista español. 
Historia del humor político del Perú - Caricatura - Anecdotario - Dibujo humorístico político

http://www.vizcarra.info/castellano/spanish/index.htm 